\title{
32. CALCAREOUS NANNOFOSSIL PALEOGENE BIOSTRATIGRAPHY, CÔTE D'IVOIRE-GHANA MARGINAL RIDGE, EASTERN EQUATORIAL ATLANTIC ${ }^{1}$
}

\author{
Samir Shafik, ${ }^{2}$ David K. Watkins, ${ }^{3}$ and Im Chul Shin ${ }^{4}$
}

\begin{abstract}
Paleogene sections on the Côte d'Ivoire-Ghana Marginal Ridge in the eastern Atlantic Ocean, sampled at three sites during Ocean Drilling Program Leg 159, are shown to have calcareous nannofossil assemblages in distinct packages of (sub)zones separated by hiatuses or barren sediments. The packages are different at each of the sites; all fall within the interval from late Paleocene Zone CP6 to latest Oligocene Subzone CN1a inclusive. Three packages (CP9b-CP11, CP13, and CP19) on the crest of the Marginal Ridge at Site 960, four (CP7-CP9b, CP11, CP13-?CP15, and CP17-CN1a) at nearby Site 959 on the shoulder of the Marginal Ridge, and only two (CP6-CP8a, and CP10) at the deeper Site 961, on the southern tip of the Marginal Ridge, were identified. The Paleogene section at Site 960 is thinner and less complete than at Site 959, but it is thinnest and least complete at Site 961. Conditions during most of the Paleogene were strikingly different near the crest of the Marginal Ridge (most affected by changes in sea level) compared with those on its lower slopes (where bottom currents were probably more effective in removing sediments or preventing sedimentation in an already sediment-starved area).

Hiatuses on the crest of the Marginal Ridge are more frequent than on its shoulder where the nannofossil succession is interrupted by intervals with seemingly barren sediments instead. Two short hiatuses at Site 960 are almost coincident with, and probably related to, major falls in the global sea level of $\sim 125 \mathrm{~m}$ during the earliest middle Eocene (also coeval with a hiatus at Site 959 and elsewhere in the Atlantic), and of $\sim 60 \mathrm{~m}$ during the latest Oligocene. An intervening hiatus at the same site (middle Eocene-lower Oligocene section virtually being missing) corresponds with a period of strongly fluctuating global sea level, which included three major falls.
\end{abstract}

\section{INTRODUCTION}

Cores recovered during Ocean Drilling Program (ODP) Leg 159 from the Côte d'Ivoire-Ghana Marginal Ridge in the eastern Atlantic Ocean (Fig. 1) were sampled; one sample per 1.5-m core section in most cases. These were studied in order to document the calcareous nannofossil distribution, and to provide biostratigraphic subdivision and a time framework for interpretation of the geological development of the Marginal Ridge.

The Côte d'Ivoire-Ghana Marginal Ridge, a major physiographic feature, lies at the eastern extension of the Romanche Fracture Zone, separating the Deep Ivorian Basin and the Gulf of Guinea Abyssal Plain. It was formed as a consequence of a series of events that started early in the Cretaceous with rifting of the northern South Atlantic, followed by active transform motion initially between the African and Brazilian plates, and subsequently between the evolving, extensional Deep Ivorian Basin and the newly created, bordering oceanic crust to the south. Thermal subsidence and Cenozoic sea-level changes dominated the final stage in the evolution of the Marginal Ridge.

\section{METHODS}

Assemblages were analyzed in smear slides prepared using either raw sediment samples (core-catcher samples) or sediment suspensions in distilled water (other samples). Gravitational settling was also used, in a few cases, to concentrate sparse nannofossil assemblages in critical samples. For each sample two slides were prepared, one with double the number of suspension drops used for the other.

'Mascle, J., Lohmann, G.P., and Moullade, M. (Eds.), 1998. Proc. ODP, Sci. Results, 159: College Station, TX (Ocean Drilling Program).

${ }^{2}$ Australian Geological Survey, GPO Box 378, Canberra, ACT 2601, Australia. sshafik@agso.gov.au

${ }^{3}$ Department of Geology, Nebraska-Lincoln, Lincoln, NE 69588-0340, U.S.A

${ }^{4}$ Korea Ocean Research and Development Institute, Ansan, P.O. Box 29, Seoul, 325-600, Korea.
Slides were examined with an optical microscope at $1250 \times$ magnification. At least one sample per core section was examined. Estimates for the total nannofossil abundance in a slide were determined as follows: $\mathrm{D}$ (dominant) $=>60 \%$ of all particles; $\mathrm{A}$ (abundant $)=30 \%-$ $60 \%$ of all particles; $\mathrm{C}$ (common) $=10 \%-30 \%$ of all particles; $\mathrm{F}$ (few) $=5 \%-10 \%$ of all particles; $\mathrm{R}$ (rare) $=1 \%-5 \%$ of all particles; $\mathrm{T}$ (trace) $=<1 \%$ of all particles. Estimates of nannofossil preservation are coded as follows: $\mathrm{E}$ (excellent) = pristine preservation with no overgrowth or dissolution; $\mathrm{G}$ (good) = slight dissolution and overgrowth, but all taxa are easily identifiable; $\mathrm{M}$ (moderate) = obvious signs of dissolution and overgrowth, but most specimens are readily identifiable; $\mathrm{P}$ (poor) = strong overgrowth and dissolution, and most specimens are fragmented and difficult to identify. Estimates of the relative abundances of nannofossil species were determined as follows: $\mathrm{D}$ (dominant) $=>60 \%$ of all nannofossils; $\mathrm{A}$ (abundant) $=$ $30 \%-60 \%$ of all nannofossils; $\mathrm{C}$ (common) $=10 \%-30 \%$ of all nannofossils; $\mathrm{F}$ (few) $=5 \%-10 \%$ of all nannofossils; $\mathrm{R}$ (rare) $=1 \%-5 \%$ of all nannofossils; vR (very rare) $=<1 \%$ of all nannofossils.

\section{NANNOFOSSIL DISTRIBUTION AND BIOSTRATIGRAPHY}

The distribution of nannofossils in the Paleogene sections on the Côte d'Ivoire-Ghana Marginal Ridge is given in Tables 1-5. Some of the Eocene species are illustrated in Plates 1 and 2. A biostratigraphic summary is presented in Figure 2 and is discussed below.

We have used the zonation of Okada and Bukry (1980), supplemented by a few of Martini's (1971) zonal indicators for greater biostratigraphic resolution. The zonation of Okada and Bukry (1980: the $\mathrm{CP}$ Zones/Subzones) was based originally on low-latitude oceanic assemblages (Bukry, 1973, 1975); whereas, the zonation of Martini (1971: the NP zones) was based on mid-latitude assemblages from land-based sections. Perch-Nielsen (1985) incorporated some of Bukry's (1973) (sub)zonal indicators into the definition of some of the NP Zones. 
Figure 1. Location of sites drilled during ODP Leg 159 and the neighboring African coast (in part modified after Mascle, Lohmann, Clift, et al., 1996). Site 962 contains no Paleogene calcareous nannofossils.

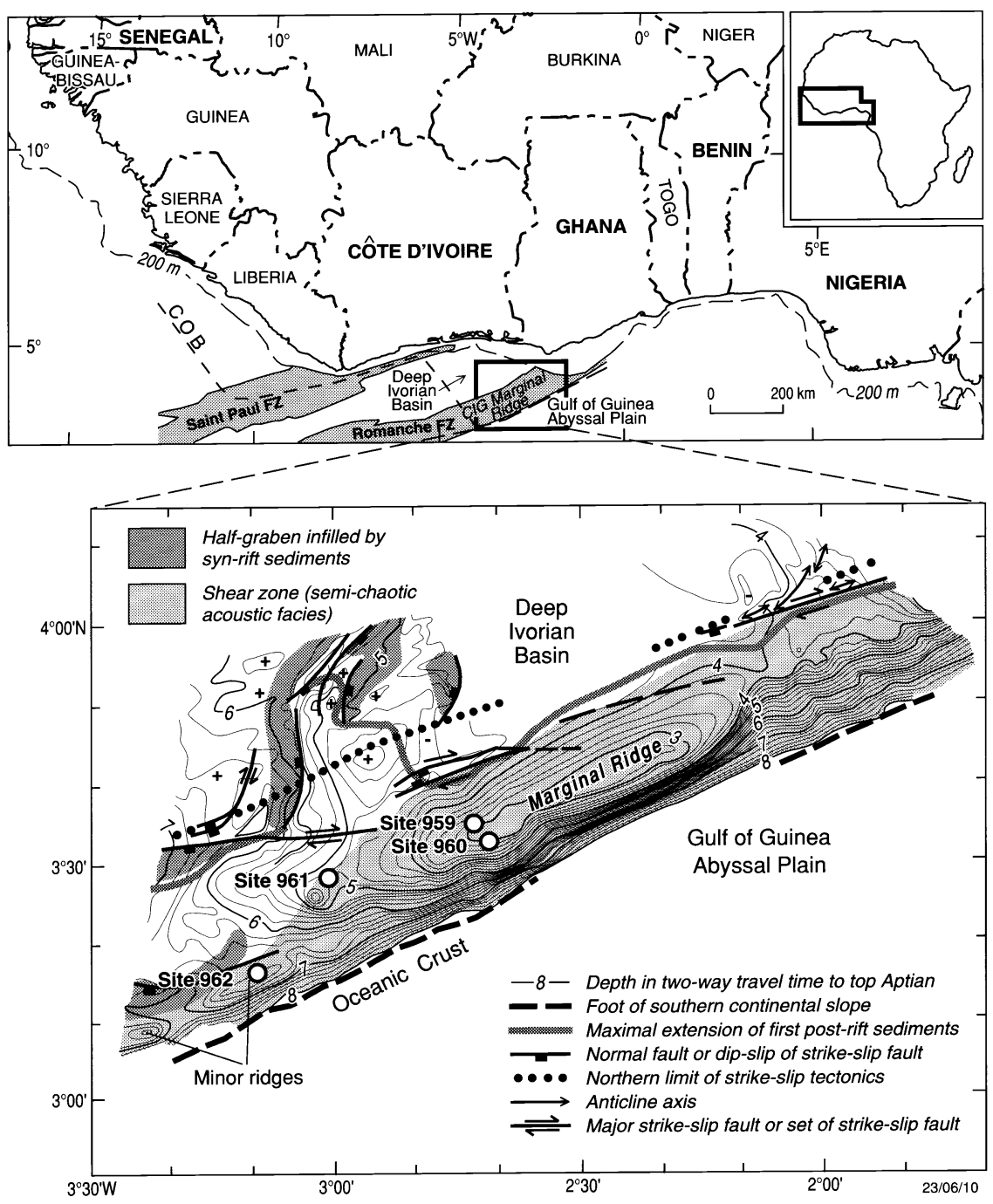

\section{Hole 959A}

(Water Depth 2090.7 m)

The basal Samples 159-959A-52X-CC through 43X-CC are barren of calcareous nannofossils. This is attributable in part to the nature of the sediment (clayey diatomite, chert, and massive claystone) and in part to the poor core recovery in this interval. Similar sediment and poor recovery characterize the depth-equivalent part of Hole 959D.

The key species Sphenolithus distentus occurs in the interval from Samples 159-959A-42X-CC through 40X-CC, but in association with Sphenolithus ciperoensis only in Section 159-959A-40X-CC (Table 1). This indicates Zone CP18 and Subzone CP19a. In Sample 159-959A-42X-CC, forms transitional between Sphenolithus distentus and S. ciperoensis are considered indicative of the upper part of Zone CP18. The absence of $S$. ciperoensis from the sparse assemblage in Sample 159-959A-41X-CC is probably due to poor preservation, and the assemblage is questionably placed in Subzone CP19a (Fig. 2). The section with assemblages readily assignable to Subzones CP19b and CN1a (Samples 159-959A-40X-1, 106-107 cm, through 32X-5, 129-130 cm; see Table 1) includes several levels that are barren of calcareous nannofossils. These are mostly within Subzone CN1a, being represented by Samples 159-959A-39X-1, 100$101 \mathrm{~cm} ; 34 X-4,102-103 \mathrm{~cm} ; 34 X-2,100-101 \mathrm{~cm} ; 33 X-7,52-53 \mathrm{~cm}$; $33 \mathrm{X}-6,97-98 \mathrm{~cm}$; and 33X-3, 100-101 cm.
Dictyococcites bisectus is rare, and several other mid- to highlatitude species (such as holococcolith Zygrhablithus bijugatus, and Pontosphaera pygmaea) are absent (see Table 1). This is consistent with a dominantly open marine, oceanic setting, at low latitude during the late Oligocene.

In this hole, we recovered the only seemingly complete succession of nannofossil assemblages across the Oligocene/Miocene boundary on the Côte d'Ivoire-Ghana Marginal Ridge (see Fig. 2 for comparison with other holes). Criteria for recognition of this boundary vary between authors (compare, e.g., Martini, 1971; Bukry, 1973; Gartner, 1974; and Martini, 1986), because of differences in types of sediments (oceanic vs. hemipelagic) and in geographic location of sections (e.g., latitudes). In low-latitude oceanic sections, the Oligocene/Miocene boundary is usually approximated by either the end of the acme of Cyclicargolithus abisectus or the (slightly older) last appearance datum (LAD) of Sphenolithus ciperoensis. As shown in Figure 2, we have both events in the Hole 959A cores, but adopt the former as the evidence for delineating the Oligocene/Miocene boundary. The end of the acme of $C$. abisectus, which marks the top of Subzone CN1a, is inherently difficult to locate precisely and consistently in routine or semiquantitative work; populations of this species and of Cyclicargolithus floridanus are usually difficult to separate, particularly within Zone $\mathrm{CN} 1$, adding to the difficulty of pinpointing the acme of $C$. abisectus. Nevertheless, we are fairly certain of the identification of this event in Sample 159-959A-32X-5, 129- 
Table 1. Calcareous nannofossil distribution in Hole 959A cores.

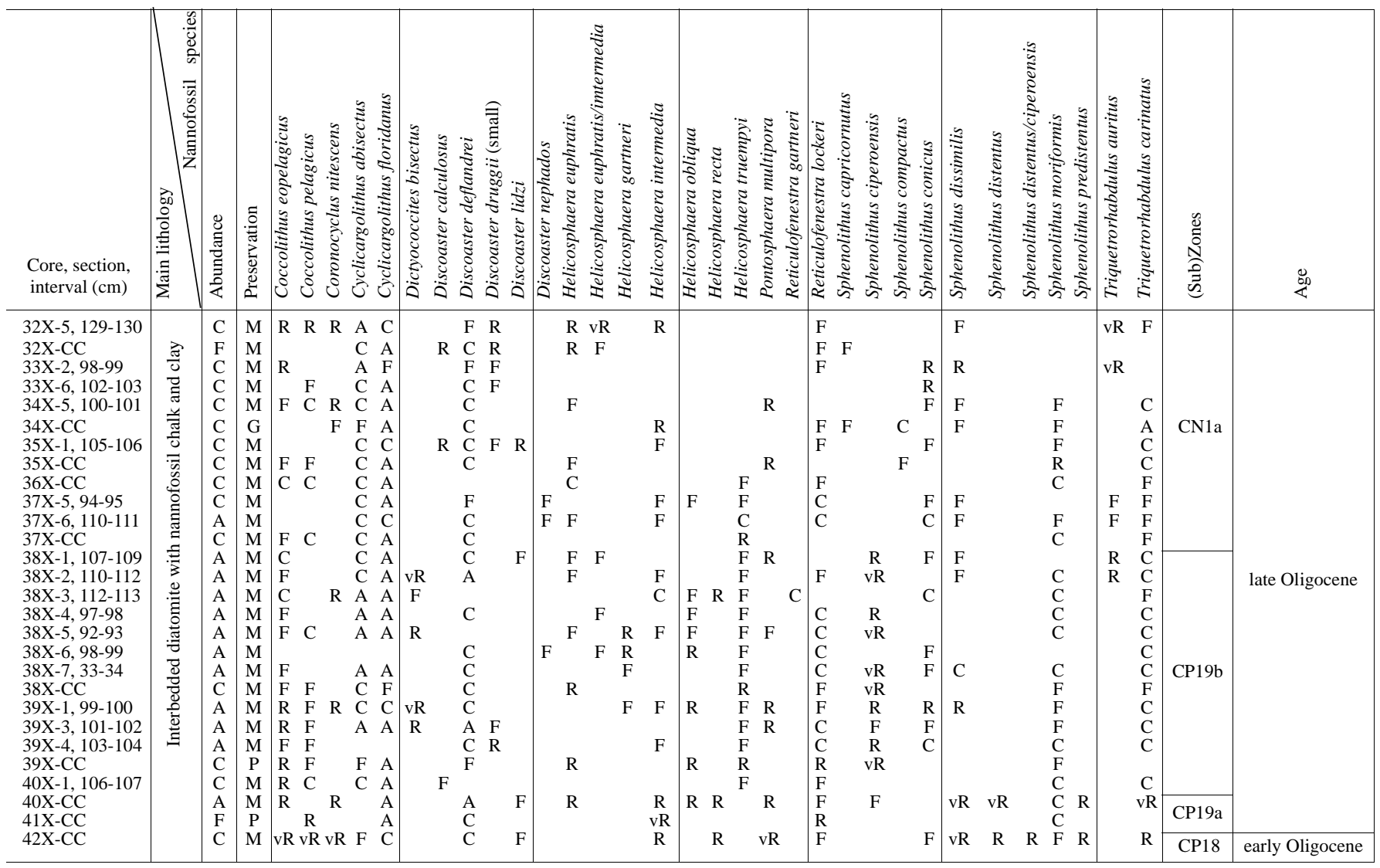

Note: Intervening samples that are barren of calcareous nannofossils are not included (for nannofossil abundance and preservation abbreviations, seethe "Introduction" section of this chapter).

$130 \mathrm{~cm}$, immediately below a barren/impoverished interval: both Samples 159-959A-32X-6, 130-131 cm, and 32X-3, 120-121 cm, are almost barren of calcareous nannofossils, with only traces of Coccolithus pelagicus, C. abisectus, and D. deflandrei; Samples 159959A-32X-2, 119-120 cm, and 32X-1, 120-121 cm, are barren of calcareous nannofossils.

Recently, the Global Stratotype Section and Point (GSSP) of the base of the Neogene (i.e., the Paleogene/Neogene or Oligocene/ Miocene boundary) has been selected in the Lemme-Carrosio Section in Italy. However, because published results on the distribution of key nannofossil species (e.g., Sphenolithus ciperoensis, and Helicosphaera recta) in this section by four workers (see Cati, 1981, p. 94-97) are difficult to reconcile, recognition of the Oligocene/ Miocene boundary elsewhere remains uncertain. In the LemmeCarrosio Section, the end of acme of Cyclicargolithus abisectus has not been yet determined (and probably does not exist in the section; see Fornaciari and Rio, 1996; text, fig. 10), and the NP25/NN1 boundary (a good approximation of the Oligocene/Miocene boundary) has been drawn by three workers (C. Müller, M. Báldi-Beke, and M. Biolzi; see Steininger, 1981) at three different levels relative to the recently selected Oligocene/Miocene boundary. (This is partly a result of possible reworking in the critical part of the section: Fornaciari and Rio [1996] show that S. ciperoensis reappears in Zone CN1; and both Dictyococcites bisectus and Zygrhablithus bijugatus range well into Zone $\mathrm{CN} 1$, above a notable decline in the already rare $C$. abisectus). Results of the IGCP Project 329 on the Lemme-Carrosio Section presented recently (Steininger and proponents of the IUGSICS-SNS Working Group on the Paleogene/Neogene boundary, 1994) show that Sphenolithus capricornutus has a very short stratigraphic range immediately above the boundary, which is bracketed by the first appearance datum (FAD) and LAD of Sphenolithus delphix. The latter species was not encountered in Hole 959A cores, and S. capricornutus was found within Subzone CN1a. Sphenolithus capricornutus, and (its associate) $S$. delphix, have been recorded previously from Oligocene sediments assignable to the CP19/NP25 zonal interval (e.g., below LAD of D. bisectus at the North Atlantic Sites 563 and 558; see Miller et al. [1985], or below the LADs of $H$. recta and $Z$. bijugatus in hemipelagic sediments in the Indian Ocean, Shafik and Chaproniere [1978]).

\section{Hole 959D (Water Depth $2090.7 \mathrm{~m}$ )}

The basal Paleogene nannofossil unit in this hole is late Paleocene Zone CP7, in Samples 159-959D-44R-3, 72-73 cm, and 44R-2, 116$117 \mathrm{~cm}$. Underlying it is a thick black claystone section (comprising Samples 159-959D-64R-CC through 44R-3, 116-117 cm), which yielded no calcareous nannofossils. The first downcore occurrence of nannofossils, below this barren claystone section, is in Sample 159959D-65R-7, $33 \mathrm{~cm}$, and this is Late Cretaceous in age (the Santonian Zone CC16 of Sissingh, 1977).

Assemblages of the zonal interval CP8-CP12a in Samples 159959D-43R-CC through 37R-1, 59-60 cm, are mostly poorly preserved, which might explain the apparent absence of zonal indicators. The succession of these assemblages in this interval is interrupted at least once by a barren section. The occurrence of Rhomboaster bitrifida in Sample 159-959D-41R-CC is used as a biostratigraphic proxy for Campylosphaera eodela to indicate Subzone CP8b. In this sample, species of the genus Fasciculithus have their highest occurrence. We used this event as a good approximation of the top of the Pale- 
Table 2. Calcareous nannofossil distribution in Hole 959D cores.

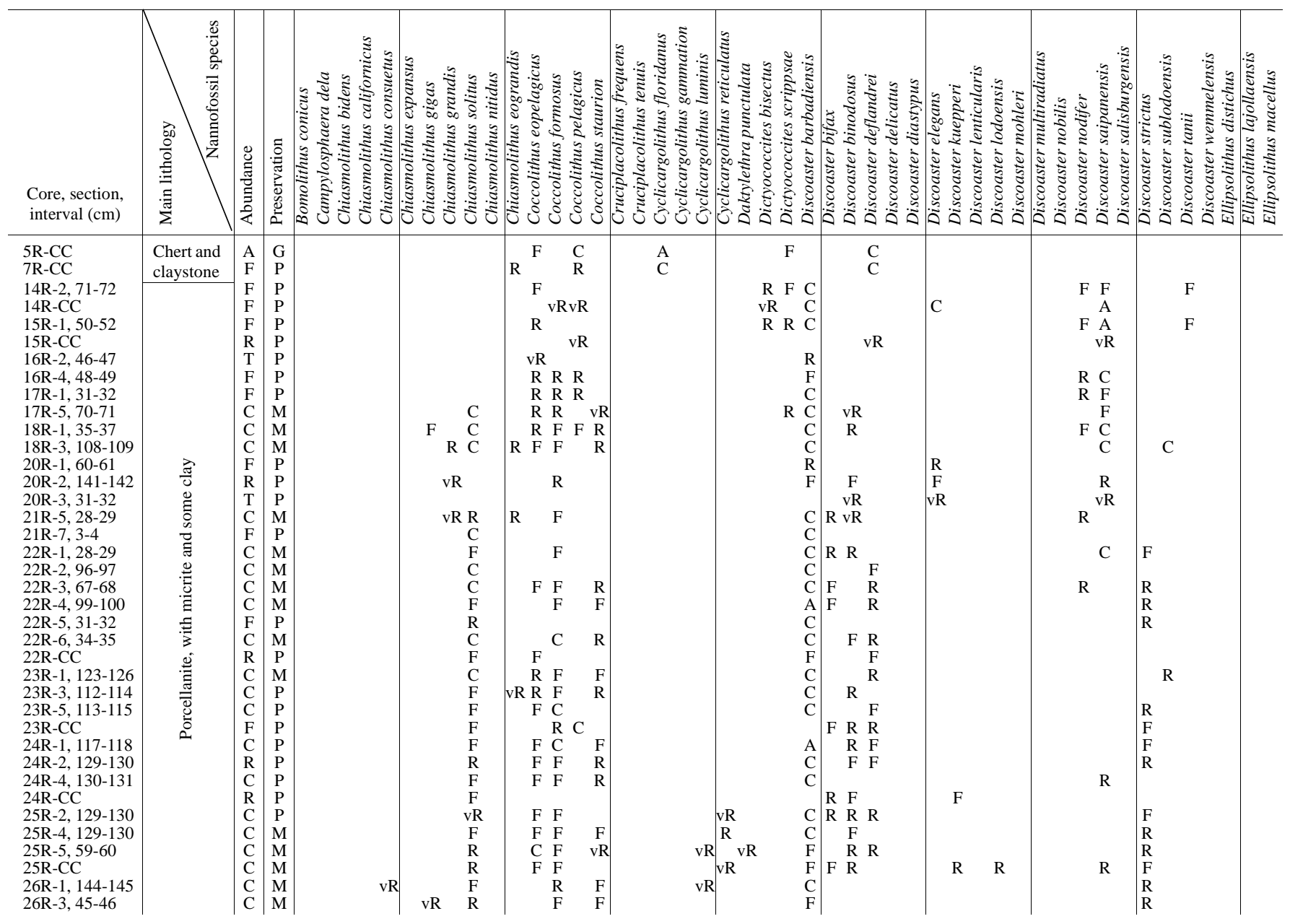

ocene. Subzone CP9a in Samples159-959D-41R-2, 96-97 cm, through 40R-3, 53-54 cm, is characterized by the occurrence of both Tribrachiatus bramlettei and T. contortus; Hornibrookina australis is present in its basal sample. A barren section, comprising Samples 159-959D-39R-3, 27-28 cm; 39R-2, 1-2 cm; and 38R-CC occurs between assemblages of Subzone CP9b (in Sample 159-959D-39R-4, 99-100 cm), and Zone CP11 (in Sample 159-959D-37R-4, 6-7 cm); Tribrachiatus orthostylus is confined to Subzone CP9b, and Coccolithus crassus (the index species of Zone CP11) was not encountered.

Zone CP13 was only tentatively subdivided (Fig. 2) because of the sporadic distribution of Chiasmolithus gigas, the index species for Subzone CP13b. This species occurs in the lower part of Zone CP13 (in Samples 159-959D-35R-6, 104-106 cm; 36R-3, 57-58 cm; and 29R-CC), as well as at the base and within the upper part of the overlying Zone CP14 (reworked in Samples 159-959D-26R-3, 45-46 cm, and $18 \mathrm{R}-1,35-37 \mathrm{~cm})$. Obvious reworking is noted in Zone CP13, particularly in its upper parts. Older species, such as Discoaster lodoensis and Tribrachiatus orthostylus, are present in samples from Cores 159-959D-29R through 27R. The holococcolith Zygrhablithus bijugatus occurs in Cores 159-959D-29R and 28R.

We used the FAD of Reticulofenestra umbilicus $(>11 \mu \mathrm{m})$ to identify the base of Zone CP14 (in Sample 159-959D-26R-3, 45-46 cm). However, the top of this zone could not be determined because of the scarcity of Chiasmolithus grandis, and the absence of $C$. oamaruensis; the top of Zone CP14 or the base of Zone CP15 are usually defined by the LAD of $C$. grandis (mainly at low latitudes) or the FAD of $C$. oamaruensis (mainly at high latitudes). Chiasmolithus grandis disappears below the highest occurrence of Chiasmolithus solitus (see Table 2), where preservation is poor; the latter was used to identify the top of Subzone CP14a. The quality of preservation in Subzone CP14a fluctuates significantly, but is consistently poor in the overlying Eocene cores.

The key species Cyclicargolithus reticulatus (restricted to the interval of middle Zone CP14-Zone CP15 at mid latitudes), the holococcolith Daktylethra punctulata (important in shelfal sediments; see, e.g., Shafik, 1983), and Discoaster lodoensis (reworked probably from Zone CP10) occur in the lower part of Subzone CP14a, in Core 159-959D-25R. Reworked nannofossils are not uncommon in this subzone, and are particularly noticeable because of their better state of preservation, suggesting that they may have come from shallower, more clayey facies; Sample 159-959D-18R-3, 108-109 cm, contains a mix of poorly preserved nannofossils characteristic of Zone CP14 (including $R$. umbilicus) and older, moderately preserved nannofossils (Discoaster sublodoensis). Where there are no reworked elements, Zone CP14 key species (mainly. R. umbilicus) could be identified in spite of the poor preservation of some of the assemblages. For example, in most samples from Core 159-959D-20R, which evidently was subjected to intense dissolution and fragmentation (most specimens are corroded, and nannofossil debris abounds), identifiable nannofossils are reduced to a few species, but these include $R$. umbilicus. The worst case is Sample 159-959D-20R-1, 60$61 \mathrm{~cm}$, in which only two species could be identified: $D$. barbadiensis/elegans and R. umbilicus.

Samples 159-959D-16R-CC through 14R-CC contain sparse, poorly preserved assemblages with identifiable species of a generalized middle to late Eocene age. These are assigned to the broad zonal 
Table 2 (continued).

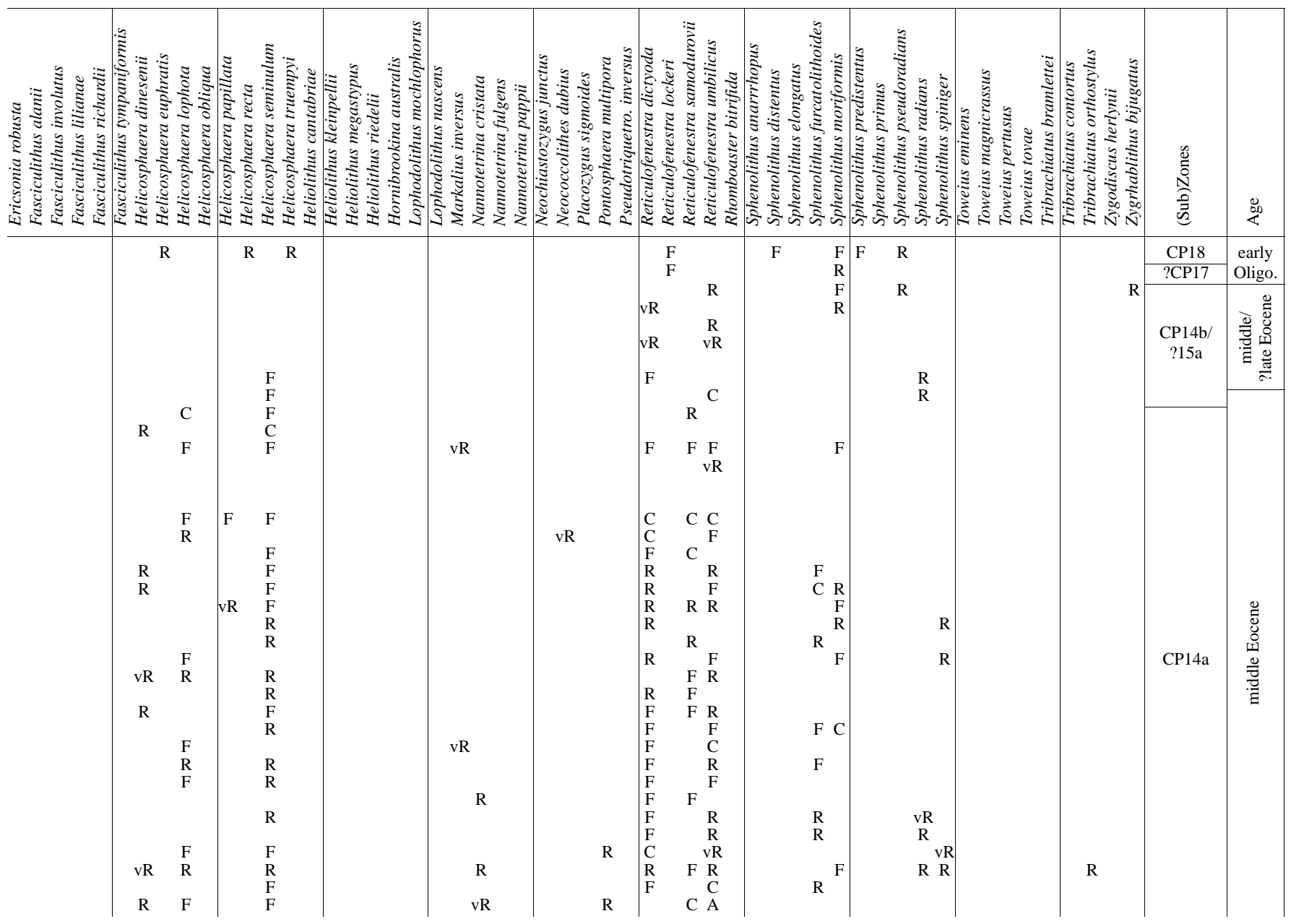

interval CP14b-CP15. The interval of Cores 159-959D-13R through $9 \mathrm{R}$ is barren of calcareous nannofossils.

The first eight cores in this hole are approximately depth equivalents of the last eight cores in Hole 959A, and likewise came from a sequence of diatomite, chert, and claystone, mostly barren of calcareous nannofossils. Only Samples 159-959D-7R-CC and 5R-CC yielded nannofossils and they are assigned to Zones CP17 and CP18 respectively. Identification of Zone CP17 relies on negative evidence (the absence of both Sphenolithus distentus and Reticulofenestra umbilicus). Because of poor preservation and scarcity of fossils, assignment to this gap zone is somewhat uncertain. Zone CP18 assemblages contains Dictyococcites scrippsae, Helicosphaera recta, Sphenolithus distentus, Sphenolithus predistentus, and S. pseudoradians; zonal assignment is more certain than below.

\section{Hole 960A}

\section{(Water Depth 2048.3 m)}

The base of the nannofossil-bearing Paleogene section in this hole is within the 26-cm-long Section 159-960A-20R-CC. A (dark) bluish green claystone sample from this section yielded traces of a poorly preserved assemblage assignable to Subzone CP9b (Table 3), but a sample from a lighter component mixed in with the same claystone produced a diverse assemblage indicative of Late Cretaceous age (Coniacian-Santonian). All samples examined from below Core 159960A-20R (down to Sample 159-960A-34R-CC) are barren of calcareous nannofossils. Preservation of nannofossils in the palygorskite claystone of Core 159-960A-20R is poor (Table 3), with total loss in at least two levels (represented by Samples 20R-CC, 8-9 cm, and 20R-1, $9 \mathrm{~cm}$ ). The few nannofossils in Sample 159-960A-20R-1, 2-3 cm, include Tribrachiatus orthostylus, Discoaster binodosus, Chiasmolithus grandis, and Sphenolithus radians, and suggest Subzone $\mathrm{CP} 9 \mathrm{~b}$.

The lithological unit comprising Cores 159-960A-19R through $16 \mathrm{R}$ consists of chert, porcellanite, and claystone. Core recovery was very poor, and preservation of calcareous nannofossils is generally poor, with Samples 159-960A-19R-CC and 19R-1, 33-34 cm, being barren; there was no core recovery for Core 159-960A-18R. Assemblages in Sections 159-960A-17R-CC and 16R-CC show contrasting states of preservation: a residual assemblage (a concentration of ortholiths and a few coccoliths) in the former assignable to Zone $\mathrm{CP} 10$; and a moderately preserved, more diverse assemblage in the latter assignable to Zone CP11. The key species of Zone CP11, Coccolithus crassus, was not found.

The quality of preservation of Subzone CP12a in the poorly recovered Core 159-960A-15R alternates sharply with concomitant species diversity changes. For example, only traces of discoasters (pieces of broken Discoaster barbadiensis and ?D. lodoensis) occur in Sample 159-960A-15R-1, $39 \mathrm{~cm}$, whereas, a few centimeters above in the better preserved Sample 15R-1, 15-16 cm, several coccolith species (e.g., Chiasmolithus grandis, C. solitus, Coccolithus formosus, and Reticulofenestra dictyoda) and a larger number of Discoaster species occur.

Several species of the genus Sphenolithus, including S. elongatus, S. furcatolithoides, S. orphanknollensis, and S. radians, are particularly notable among the assemblages of Zone CP13 recovered from 
Table 2 (continued).

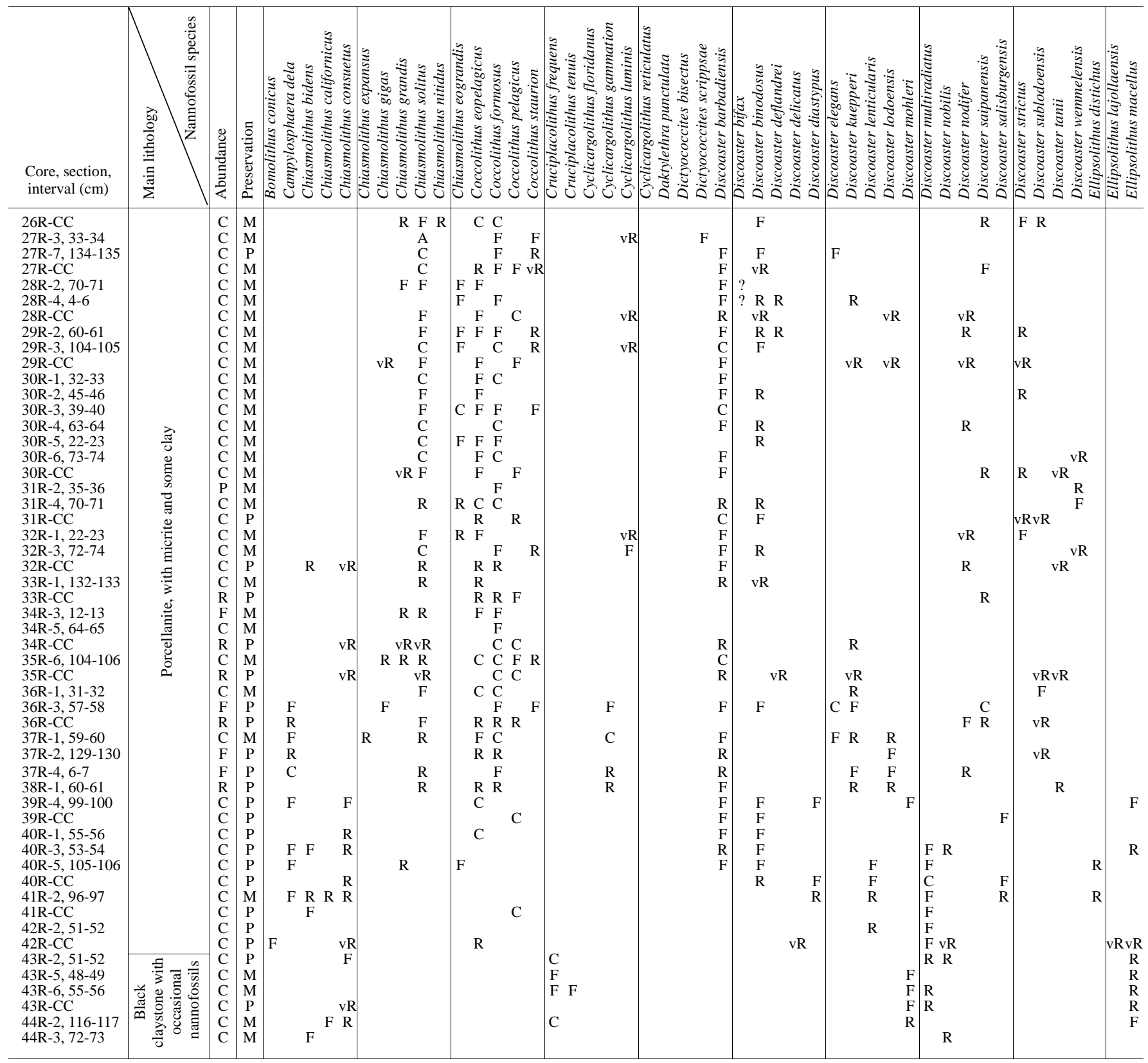

Note: Intervening samples that are barren of calcareous nannofossils are not included (for nannofossil abundance and preservation abbreviations, see the "Introduction" section of this chapter).

Core 159-960A-14R. The nannofossils in Sample 159-960A-14R-1, $9 \mathrm{~cm}$, contain the only occurrence of the key species Chiasmolithus gigas in the hole, which together with Nannotetrina fulgens, indicates Subzone CP13b.

A barren interval occurs above the Subzone CP13a assemblage, extending to within Core 159-960A-12R (i.e., from Sample 159960A-14R-1, $4 \mathrm{~cm}$, to Sample 159-960A-12R-2, 120-121 cm, inclusive). However, a sample from the core catcher of the poorly recovered Core 159-960A-13R contains sparse, very poorly preserved nannofossils. Only traces of Cyclicargolithus floridanus and Triquetrorhabdulus carinatus were found, which suggest a late Oligocene age (probably Subzone CP19a); other samples examined from the same core catcher are barren of calcareous nannofossils.

The youngest Paleogene assemblage in this hole occurs in Sample 159-960A-12R-2, 94-95 cm. This is assigned to the late Oligocene
Subzone CP19b. Immediately above, in Sample 159-960A-12R-2, $73-74 \mathrm{~cm}$, the early Miocene Subzone CN1b was identified (Fig. 2). All samples examined from Core 159-960A-12R, below 12R-2, 94$95 \mathrm{~cm}$, lack calcareous nannofossils.

\section{Hole 960C (Water Depth $2034.9 \mathrm{~m}$ )}

The basic biostratigraphic framework in this hole is similar to that in Hole 960A. Minor differences in their detail can be attributed largely to differences in sampling and core recovery. Rotary drilling (RCB) in Hole 960A limited recovery rates throughout the Paleogene from one to three sections per core; but a combination of advanced piston corer (APC) and XCB in Hole 960C provided excellent recovery rates through most of the Paleogene. 
Table 2 (continued).

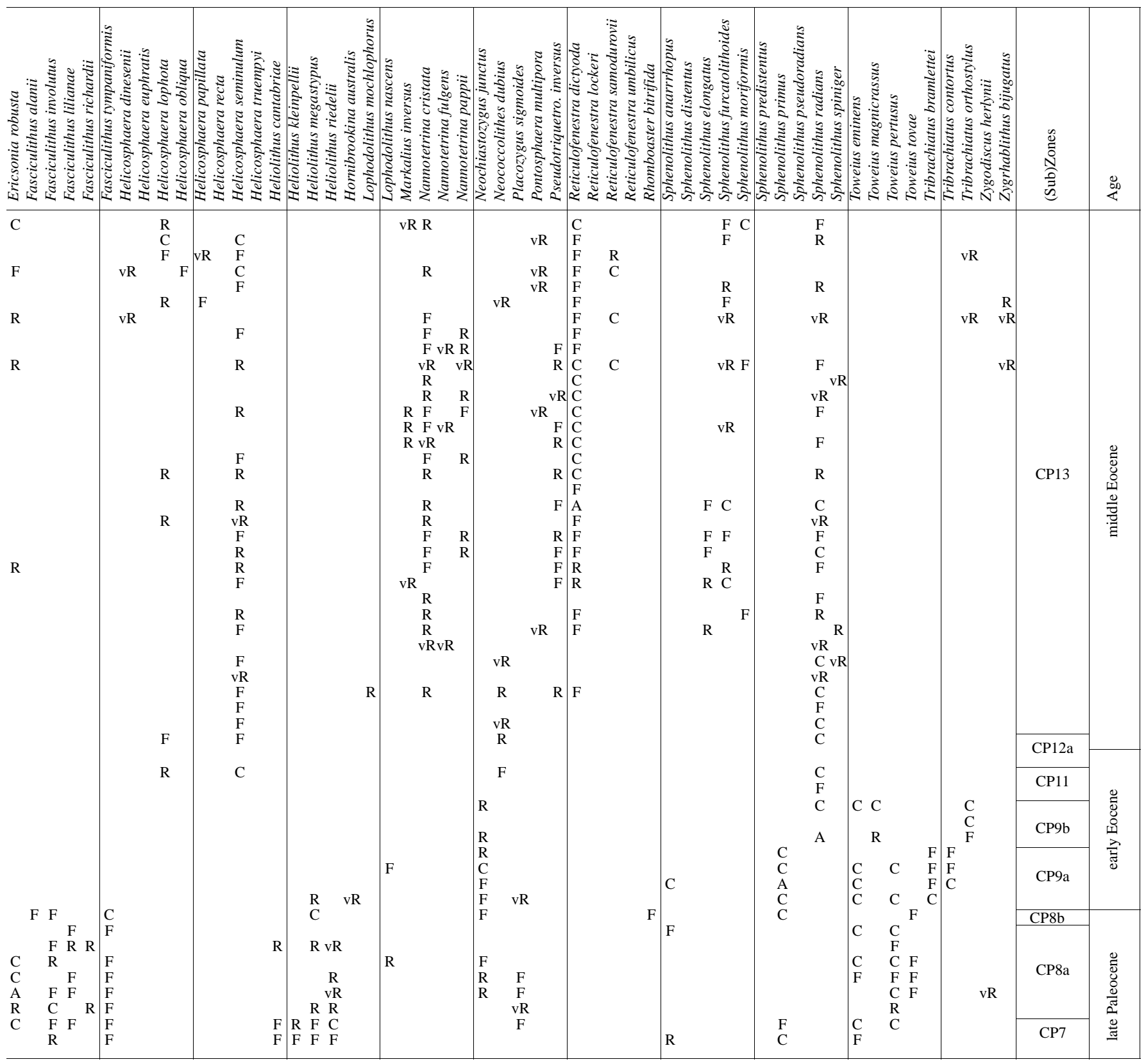

The base of the nannofossil-bearing Paleogene section in this hole is within Core 159-960C-23X: rare, strongly corroded nannofossils in Section 159-960C-23X-1 suggest an early Eocene age (Table 4); whereas, those (also rare) in Section 159-960C-23X-CC are indicative of a Late Cretaceous age (the Coniacian Zone CC14 of Sissingh, 1977); the two levels are $23 \mathrm{~cm}$ apart. The most diverse assemblage in Section 159-960C-23X-1 (at $26 \mathrm{~cm}$ level; Table 4) consists mostly of ortholiths, which were concentrated as the less resistant nannoliths dissolved. These are Tribrachiatus orthostylus, Discoaster barbadiensis/elegans, D. binodosus, D. diastypus, and D. kuepperi, assignable to Subzone CP9b.

Assemblages of Zone CP10 occur in Cores 159-960C-22X through 19X. These cores (like the underlying Core 23X) came from hard lithologic units (e.g., chert, porcellanite, and claystones; see Table 4), where both core recovery and preservation of calcareous microfossils are very poor. Samples from the top of Section 159960C-22X-CC, and from Section 159-960C-21X-CC were barren of calcareous nannofossils. The assemblage in a sample from the bottom of Section 159-960C-22X-CC contains the only occurrence of Tribrachiatus contortus in this hole, in association with Discoaster lodoensis (Table 4). Ortholiths in this sample show two states of preservation. This, together with the co-occurrence of the mutually exclusive species $D$. lodoensis and $T$. contortus, suggests some mixing/ reworking; the earliest appearance of $D$. lodoensis defines the base of Zone CP10; whereas, T. contortus is known to be restricted to Subzone CP9a.

Only traces of nannofossils, limited to a few strongly corroded $D$. barbadiensis specimens, occur in Sample 159-960C-18X-2, 14-15 $\mathrm{cm}$. These separate the assemblages of Zone CP11 and Subzone 12a (see Table 4). Assemblages assignable to Subzone CP13a occur in 
Table 3. Calcareous nannofossil distribution in Hole 960A cores.

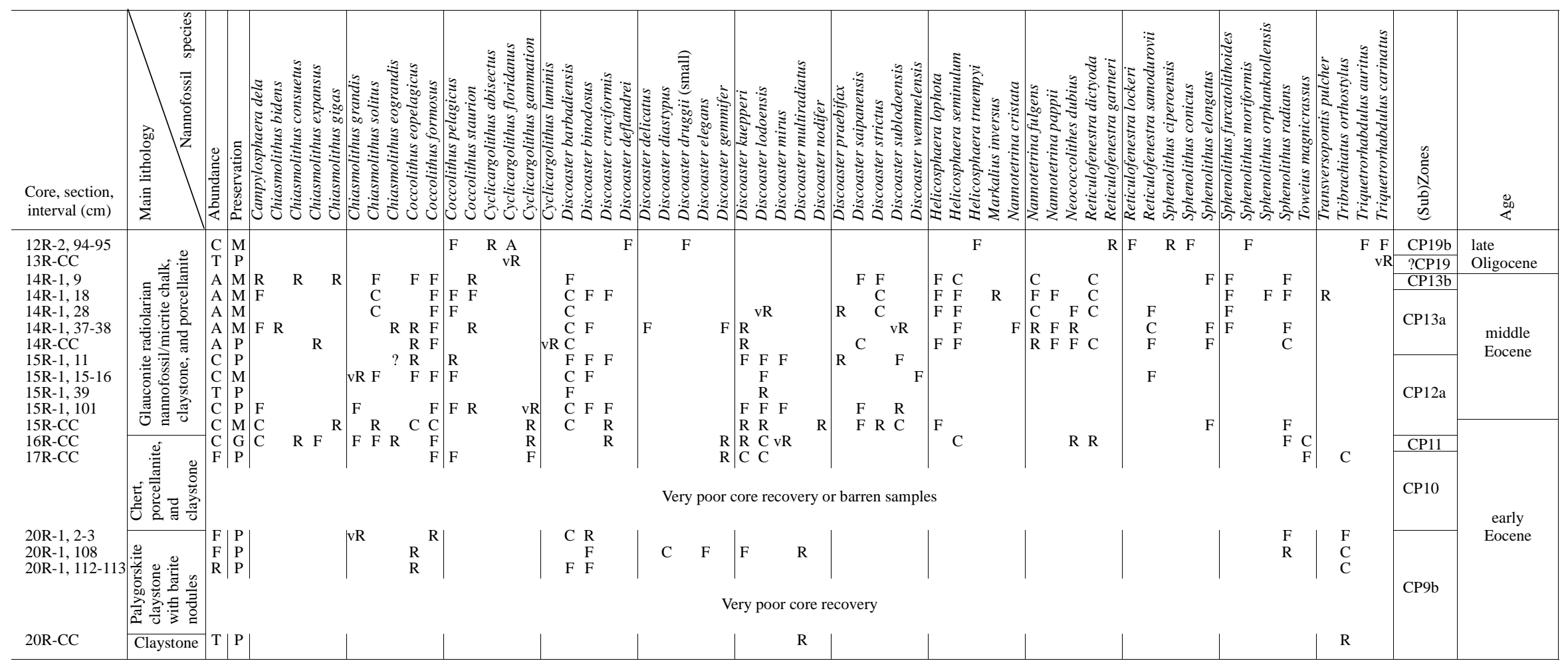

Note: Intervening samples that are barren of calcareous nannofossils are not included (for nannofossil abundance and preservation abbreviations, see the "Introduction" section of this chapter. 
Cores $159-960 \mathrm{C}-17 \mathrm{X}$ and $16 \mathrm{H}$. These include species of the largely hemipelagic genus Transversopontis.

A barren section of $>10 \mathrm{~m}$ of glauconitic claystone and radiolarite (comprising all of Core 159-960C-15H and Sample 159-960C-14H7, 34-35 cm), separates middle Eocene Subzone CP13a (in Sample 159-960C-16H-1, $75 \mathrm{~cm}$ ) and Subzone CP19a (in Sample 159-960C$14 \mathrm{H}-6,34-35 \mathrm{~cm})$. A middle Eocene radiolarian fauna was extracted from Core 159-960C-15H, and assigned to the Podocyrtis chalara Zone (Shipboard Scientific Party, 1996a), indicating that the gap in the nannofossil record between Subzones CP13a and CP19a is largely a hiatus. The barren interval is probably restricted to the middle Eocene (see Fig. 2): the radiolarian Podocyrtis chalara Zone is correlative with the lower part of Subzone CP14b (see, e.g., correlation chart in Haq et al., 1988).

Similarly to Hole 960A, the youngest Paleogene nannofossils in this hole are assignable to the late Oligocene Subzone CP19b (Table 4), but identification of Subzone CP19a is more certain in this hole. Both Sphenolithus distentus and S. predistentus are present, and the better preserved assemblages are much more diverse. The solutionprone Zygrhablithus bijugatus (known to have preferred higher latitudes) and Pontosphaera multipora are present, albeit rarely, among assemblages showing signs of mild dissolution in the upper samples of Zone CP19.

\section{Hole 961A (Water Depth 3292 m)}

The nannofossil-bearing Paleogene section in this hole is thin, comprising Core 159-961A-20R through to within the base of Core 159-961A-17R; the underlying thick section (down to Core 159961A-35R) is barren of calcareous nannofossils. The basal assemblages, in Samples 159-961A-20R-CC and 20R-1, 111-113 cm, are assignable to late Paleocene Zone CP6. These include rare Prediscosphaera cretacea, reworked from a Cretaceous source. Sample 159-961A-20R-2, 90-91 cm, within Zone CP6, is barren of calcareous nannofossils.

Zone CP7 nannofossils, in Samples 159-961A-20R-1, 15-16 cm, and 19R-CC, are characterized by a high diversity of the genera Heliolithus and Fasciculithus. Species of the genus Fasciculithus continue in Subzone CP8a above, in samples from Section 159961A-19R-1, but are absent from overlying cores, indicating the top of the Paleocene in the hole.

Early Eocene Zone CP10 in Sample 159-961A-17R-CC is based on the association of Cyclicargolithus gammation, Chiphragmalithus acanthodes, C. calathus, Discoaster kuepperi, and T. orthostylus; Discoaster lodoensis is absent from this sample, but occurs in the underlying core. Other samples examined from Core 159-961A-17R are devoid of calcareous nannofossils. The radiolarian fauna recovered from this core is suggestive of the combined Buryella clinataPhormocyrtis striata striata Zones of early Eocene age (Shipboard Scientific Party, 1996b). These zones have been shown to correlate with upper Zone CP11 to within Subzone CP12a (see, e.g., chart in Haq et al., 1988). Accordingly, the barren interval (barren samples from Core 961A-17R) above Zone CP10 in Figure 2 is extended to within the lower part of Subzone CP12a.

Core 159-961A-16R is also devoid of calcareous nannofossils, and the first upcore occurrence of nannofossils, in Core 159-961A$15 \mathrm{R}$, is indicative of the early Miocene Subzone CN1c. Radiolarians in Core 159-961A-16R were assigned to the early Miocene Lychnocanoma elongata Zone age (Shipboard Scientific Party, 1996b). This indicates a substantial hiatus between lower Eocene and lower Miocene sediments (Cores 159-961A-17R and 16R, respectively).

\section{Eocene Deposition Depth: Comparison with Onshore Sections}

Claystones dominated by the mineral palygorskite were recovered in the lower Eocene sediments at Sites 960 and 961 (see Mascle,
Lohmann, Clift, et al., 1996); these are assigned to Subzone CP9b and Zone CP10 at Site 960 (see Tables 3 and 4), and mainly to Zone CP10 at Site 961 (Table 5). The comparatively pure occurrences of this mineral, particularly at Site 960, suggest an authigenic origin, requiring conditions of elevated temperatures and increased salinities (Mascle, Lohmann, Clift, et al., 1996, with references). This indicates shallowing on the Marginal Ridge by uplift or sea-level fall, producing locally restricted, warm, hypersaline conditions (Mascle, Lohmann, Clift, et al., 1996). Where the nannofossils occur in the Eocene sections on the Marginal Ridge, they provide evidence for open marine, oceanic conditions; this is also true for the Paleocene and Oligocene sections

Calcareous nannofossil assemblages assignable to the zonal interval CP9b-CP13b have been documented in land-based sections in neighboring equatorial West Africa. Differences between these assemblages and coeval assemblages in ODP Leg 159 cores are obvious (discussed below) and support the conclusion that at this time deposition on the Côte d'Ivoire-Ghana Marginal Ridge was under oceanic conditions (i.e., in an open marine setting).

Eocene nannofossil assemblages in neritic sections in Nigeria, Benin, and Sénégal (Fig. 1) have been shown to consistently contain taxa indicative of depositional environments akin to continental shelf, or epicontinental or marginal sea (e.g., pentaliths, pontosphaerids, and holococcoliths; see, Perch-Nielsen and Petters, 1981; Akpiti et al., 1982; Toumarkine et al., 1984). Thus, in an outcrop of the Ameke Formation in the southern Benue Trough in Nigeria, assemblages of Subzone CP13b contain a large number of hemipelagic species, with most of the genera Pontosphaera, Pemma, Holodiscolithus, Micrantholithus, Transversopontis, Trochoaster, and Zygrhablithus being well represented (Perch-Nielsen and Petters, 1981). Similarly, a large number of species of most of the same genera were reported among diverse assemblages assignable to Zones CP12 and CP13 from a section in Benin (Akpiti et al., 1982). In a bore in the Cap Vert area in Sénégal, assemblages of Zones NP11 and NP12 (Subzone CP9b and Zone CP10) contain T. pulcher, T. pulcheroides, and Z. bijugatus (Toumarkine et al., 1984). In contrast, in the Eocene (and Oligocene) on the Côte d'Ivoire-Ghana Marginal Ridge, none of the pentaliths (e.g., Pemma and Micrantholithus) are present, and the holococcoliths (e.g., Holodiscolithus and Zygrhablithus) are restricted to only a few occurrences of $Z$. bijugatus. These are in the middle Eocene Zones CP13 and CP14 at Site 959 (Table 4), where reworking is suspected (e.g., Discoaster lodoensis being present), but also include a single occurrence in the upper Oligocene at Site 960. The usually diverse genus Pontosphaera (in neritic/land-based sections) is limited to a single species, $P$. multipora. This species occurs mainly in Zones CP13 and CP14 at Site 959 as a very minor component, and with Transversopontis pulcher and T. pulcheroides in Subzone CP13a at Site 960, also as a very minor component (Tables 24). None of the hemipelagic genera/species in the west African Eocene neritic sections was encountered in the lower Eocene of Sites 960 and 961 (Tables 3-5), where concentrations of the mineral palygorskite are present. This evidence, although negative, is in agreement with that from the associated benthic foraminifers that indicate lower bathyal to abyssal depth for the Eocene at Site 961 (see Mascle, Lohmann, Clift, et al., 1996).

\section{INTERVALS WITH NO NANNOFOSSIL RECORD}

One striking feature of the Paleogene sections on the Côte d'Ivoire-Ghana Marginal Ridge is the record of repeated episodes of non-deposition and/or condensed sedimentation (Site 960), or deposition of noncalcareous (black claystone/biosiliceous) sediments (Site 959; see Fig. 2). Site 960 on the crest of the Marginal Ridge was sediment starved compared to Site 959 on the shoulder of the Marginal Ridge, and its record of hiatuses (discussed below) is particularly interesting: during the Paleogene (and later) the Marginal Ridge acted as a passive margin — continually subsiding as a result of con- 
Table 4. Calcareous nannofossil distribution in Hole 960C cores.

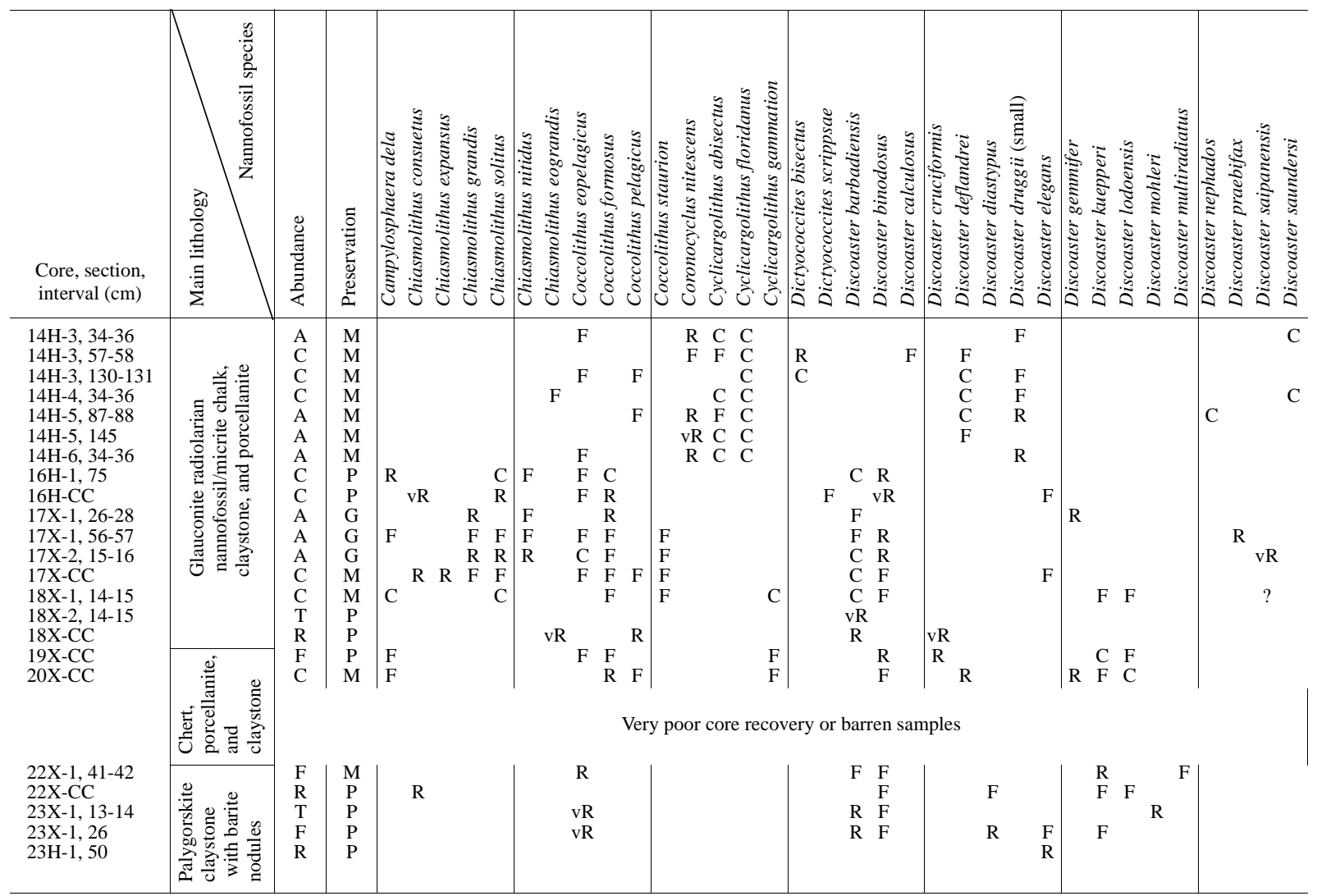

tinuing thermal decay (Mascle, Lohmann, Clift, et al., 1996, with references) - a tectonic setting conducive to accumulation of sediments rather than formation of hiatuses. Because of some parallelism between the hiatuses at Site 960 and the noncalcareous sediment packages at Site 959, the latter are also discussed below.

Down the slope of the Marginal Ridge, at Site 961, the Paleogene nannofossil-bearing section is the thinnest and least complete, indicating that conditions during most of the Paleogene were strikingly different on the lower slopes of the Marginal Ridge and near its crest. Bottom-water currents at Site 961 were probably more effective in removing sediments or preventing sedimentation in an already sediment-starved area.

That detectable hiatuses (or very condensed sections) are more frequent at Site 960 than at the other two sites (Fig. 2), is consistent with this site being on the more topographically exposed crest of the Marginal Ridge. There, favorable conditions for nondeposition or removal of sediments are likely to have been more frequent than on the shoulder of the Marginal Ridge at Site 959. Four hiatuses/condensed sections are evident at Site 960. The oldest, at the base of the Paleogene, is a $\sim 23-\mathrm{cm}$-thick section, representing the substantial time gap between the Coniacian Zone CC14 and the early Eocene Subzone $\mathrm{CP} 9 \mathrm{~b}$. The second hiatus is short, within the lower middle Eocene section (Subzone CP12a is missing). The vertical extent of the third hiatus is not immediately clear because of the presence of sediments barren of nannofossils between nannofossil assemblages of the middle Eocene Zone CP13 and the late Oligocene Zone C19. However, radiolarian fauna in the sediments in Hole 960C (discussed above) suggest that the hiatus represents essentially the time gap between early Subzone CP14b (late middle Eocene) and early Subzone CP19a (late Oligocene). The youngest hiatus is a brief one, at the top of the Oligocene between the late Oligocene Subzone CP19b and the early Miocene Subzone CN1b; the intervening Subzone CN1a (latest Oligocene) is missing.

Intervals with barren (noncalcareous) facies are more frequent at Site 959 than at the other two sites. The thick, barren black claystone section bracketed by the Santonian Zone CC16 and late Paleocene Zone CP7 at Site 959 contrasts with the Coniacian-early Eocene condensed section/hiatus at Site 960 (Fig. 2), notwithstanding that this claystone section may contain hiatus(es). Similarly, the relatively thick, barren section between the Eocene and the Oligocene nannofossil successions (Zones ?CP15 and CP17 respectively) at Site 959 has seemingly no counterpart at the other sites. Instead, a (CP14bCP19a) hiatus is present at Site 960 (Fig. 2). (The time limit of each of the two thick barren sections at Site 959 seems to be less than, but within the temporal span of, the corresponding hiatus at Site 960.) The upper Oligocene to lower Miocene section contains several barren horizons at Site 959, whereas, at Site 960 it contains a (CN1a) hiatus (Fig. 2). However, both sites share a similar earliest middle Eocene (CP12b) hiatus, and probably some of the thin and barren sediments of the lower and middle Eocene. The barren lower Eocene segment at Site 959, placed against Zone CP10 in Figure 2, corresponds well with poor preservation (residual assemblages) and mixing/reworking in Zone CP10 at Site 960.

The earliest middle Eocene (CP12b) hiatus evidently extends beyond the Côte d'Ivoire-Ghana Marginal Ridge Sites 960 and 959, being widespread in the Atlantic Ocean. Aubry (1995) has shown a striking pattern of deposition and hiatuses in the lower and middle Eocene sedimentary record of most of the Atlantic Ocean: a good 
Table 4 (continued).

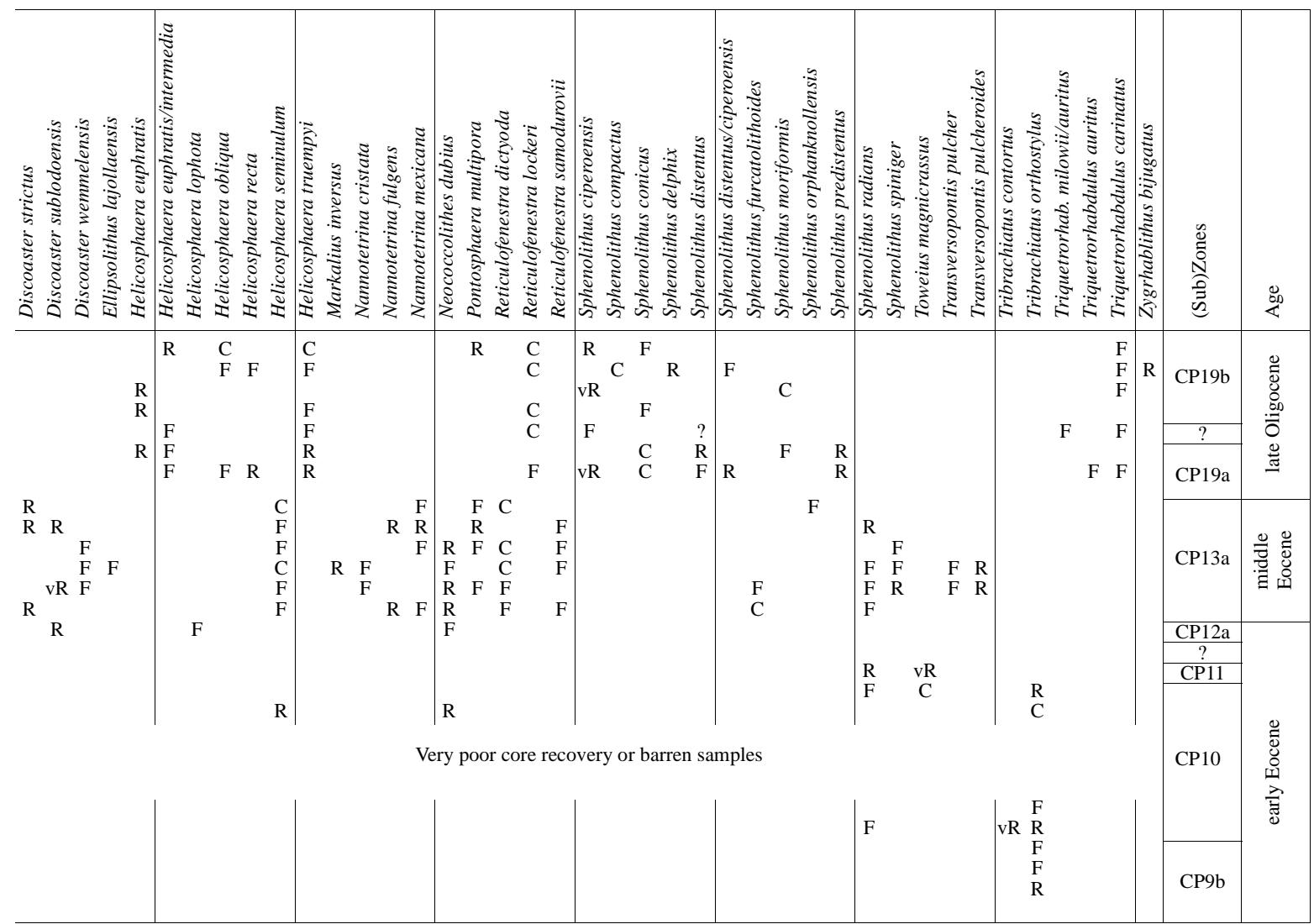

depositional record for the early Eocene (not dissimilar from that at Site 959), and two latest early and earliest middle Eocene hiatuses. The latest early Eocene hiatus roughly equates with Zone CP11, whereas the earliest middle Eocene hiatus basically corresponds with Subzone CP12b. The latter is by far the more widespread in the entire Atlantic Ocean. Subzone CP12b is not represented, for example, at most sites in the eastern South Atlantic, on the Walvis Ridge or in the Angola Basin (see Aubry, 1995, fig. 39). At the nearby Deep Sea Drilling Project Site 366, on the Sierra Leone Rise, the critical part of the section is not well constrained biostratigraphically because of poor core recovery, although diverse foraminiferal and nannofossil assemblages are present. However, Aubry (1995) was able to infer an unconformity (most of Subzone CP12b and basal CP13a are missing), at or near which evidence of mixing resulting from reworking or intensive burrowing was detected.

Significant environmental changes must have occurred repeatedly during the Eocene and Oligocene to account for the frequency of hiatuses on the crest of the Côte d'Ivoire-Ghana Marginal Ridge (Site 960), and the repeated deposition of noncalcareous facies on the shoulder of the same ridge (Site 959); the oldest Coniacian-early Eocene hiatus at Site 960 and its corresponding barren section at Site 959 have already been explained (see Mascle, Lohmann, Clift, et al., 1996) and are not discussed further herein. Environmental changes are likely to be driven largely by movements in sea level, which could be induced eustatically and/or tectonically. For eustatic movements in sea level to be the primary force for the changes, the hiatuses should correspond with times of, or immediately follow, global sealevel falls. This seems to be the case at two levels within the middle Eocene and upper Oligocene sections of Site 960 (see below). Tectonically controlled movements in sea level are not demonstrated as easily.
In Figure 3, we attempt to show possible correlations between the hiatuses at Site 960 on the crest of the Côte d'Ivoire-Ghana Marginal Ridge and oceanic hiatuses (compiled by Keller et al., 1987) and global sea-level falls. In this figure, the sea-level curve of Haq et al. (1987) is modified to conform with the time scale of Berggren et al. (1995). This is achieved by converting the ages of the magnetic polarity reversals from those given in Haq et al. (1987) to those of Cande and Kent (1992); the polarity reversals are preferred, rather than any of the microfossil zonations, for the change to the time scale of Berggren et al. (1995).

The widespread earliest middle Eocene (CP12b) hiatus at Sites 960 and 959 (and other sites in the Atlantic Ocean; see Aubry, 1995) corresponds with a globally depressed sea level that immediately followed a major early/middle Eocene drop of $\sim 125 \mathrm{~m}$ (Fig. 3). A good match is evident between the youngest hiatus, at the top of the Oligocene, at Site 960, and the hiatus PHa of Keller et al. (1987). These seem to be coincident with, and probably related to, the $\sim 60-\mathrm{m}$ drop in sea level that occurred during the latest Oligocene/earliest Miocene (Fig. 3). The intervening CP14b-CP19a hiatus at Site 960 corresponds with times of a fluctuating, generally elevated global sea level, which included three major falls (Fig. 3). Significantly, about halfway through this hiatus (and also the corresponding barren section at Site 959) is the hiatus PHc of Keller et al. (1987) (Fig. 3). The latter is almost coincident with the $\sim 80 \mathrm{~m}$ drop in sea level that occurred close to the Eocene/Oligocene boundary.

\section{REMARKS AND CONCLUSION}

The calcareous planktonic Paleogene section on the Côte d'Ivoire-Ghana Marginal Ridge was formed in open marine, oceanic, 
Table 5. Calcareous nannofossil distribution in Hole 961A cores.

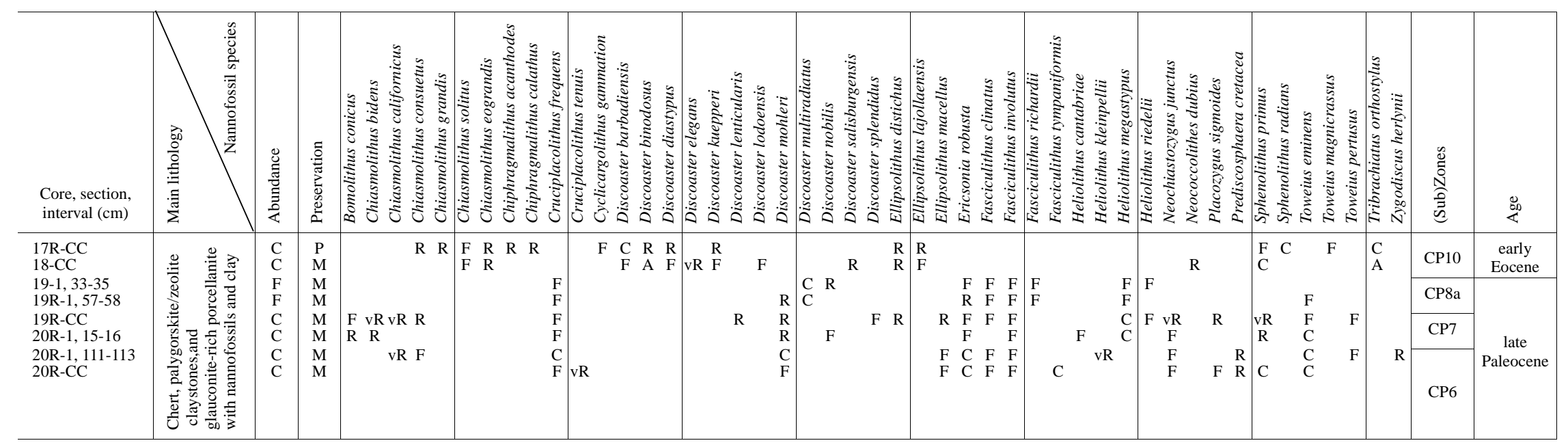

Note: Intervening samples that are barren of calcareous nannofossils are not included (for nannofossil abundance and preservation abbreviations, see the "Introduction" section of this chapter. 


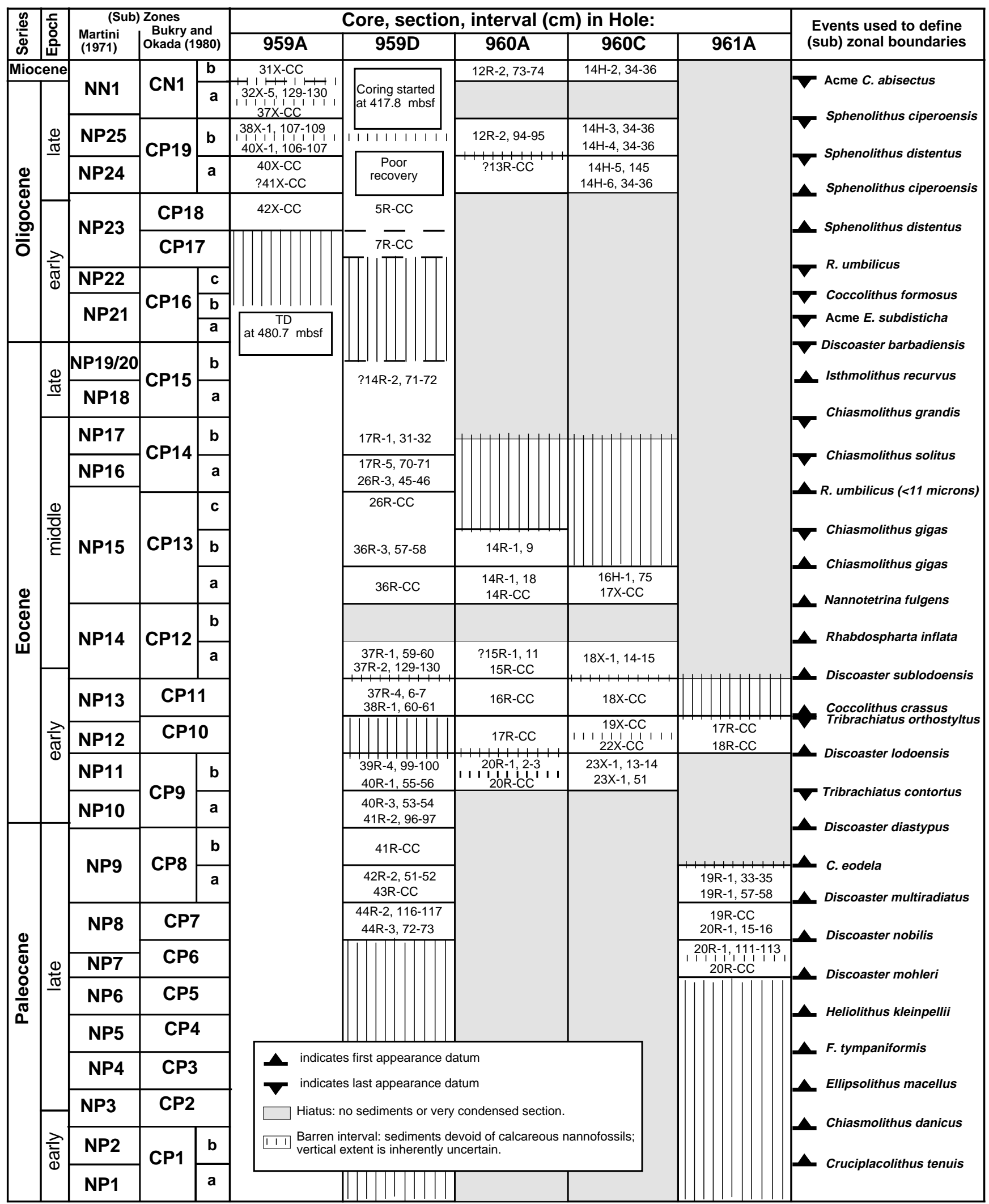

Figure 2. Summary of the Paleogene calcareous nannofossil biostratigraphy on the Côte d'Ivoire-Ghana Marginal Ridge, ODP Leg 159 . The vertical extent of the barren middle Eocene sediments at Site 960 is based on a radiolarian fauna in the sediments in Hole 960C (see text). Also, the vertical extent of both the barren lower Eocene sediments in Hole 961A and the overlying hiatus are based primarily on radiolarian fauna in these and overlying sediments (see text). 
low-latitude settings, largely affected by eustatic sea-level changes, and in places, by erosive bottom currents. The base of this section appears to become younger up the ridge: it is late Paleocene (CP6 Zone) on the lower slopes (Site 961), later Paleocene (CP7 Zone) on the shoulder of the ridge (Site 959), and early Eocene (Subzone CP9b) higher up on the crest of the ridge (Site 960). This section is discontinuous: on the crest of the ridge it is interrupted principally by hiatuses, whereas on the shoulder of the ridge it is segmented by mainly barren (noncalcareous) sediment packages. The hiatuses on the crest of the Marginal Ridge generally correspond in time with the barren sediments on the shoulder of the Marginal Ridge; however, at both locations the same earliest middle Eocene (CP12b) hiatus occurs, which is evidently widespread in the Atlantic. The timing of individual post-Paleocene hiatuses or barren sediment packages roughly coincides with eustatic falls in sea level, suggesting a close relationship.

Among the major boundaries limiting or subdividing the Paleogene section on the Côte d'Ivoire-Ghana Marginal Ridge, the Cretaceous/Tertiary and Eocene/Oligocene boundaries fall within unsuitable (barren) facies or hiatuses. Cores containing the Paleocene/ Eocene and Oligocene/Miocene boundaries from the Marginal Ridge bear nannofossils. The former boundary is conveniently approximated by the highest occurrence of Fasciculithus spp.

The nannofossil biostratigraphy in the recently selected GSSP of the base of the Neogene (Lemme-Carrosio Section, Italy) is not yet clear, and its impact, if any, remains to be seen on the recognition of the Oligocene/Miocene boundary by means of nannofossils elsewhere. The end of the acme of Cyclicargolithus abisectus (seemingly unrecognizable in the Italian section) is used here for approximation of this boundary. Both Sphenolithus delphix and S. capriconutus, whose presence emerges from studies of the Lemme-Carrosio Section as possibly good evidence for the Oligocene/Miocene boundary, are already known from older sediments.

\section{ACKNOWLEDGMENTS}

We thank both Katharina von Salis (Geological Institute, ETH, Zurich, Switzerland) and Wuchang Wei (Scripps Institute of Oceanography, University of California) who reviewed this paper, for their constructive criticism of the manuscript. The senior author thanks both N.F. Exon (Australian Geological Survey Organisation, Canberra) and M. Moullade (Université de Nice-Sophia Antipolis, France) for their helpful review of an earlier draft manuscript. This paper is published with permission of the Executive Director of the Australian Geological Survey Organisation, Canberra.

\section{REFERENCES}

Akpiti, S., De Klasz, I, Le Calvez, Y., Perch-Nielsen, K., and Toumarkine, M., 1982. Biostratigraphie de l'Éocène de la région de Zougbonou (SW de la République Populaire du Bénin, Afrique Occidentale). Cah. Micropaleontol., 2:81-90.

Aubry, M.-P., 1995. From chronology to stratigraphy: interpreting the lower and middle Eocene stratigraphic record in the Atlantic Ocean. In Berggren, W.A., Kent, D.V., Aubry, M.-P., and Hardenbol, J. (Eds.), Geochronology, Time Scales, and Global Stratigraphic Correlation: A Unified Temporal Framework for an Historical Geology. Spec. Publ.-Soc. Econ. Palaeontol. Mineral., 54:213-274.

Berggren, W.A., Kent, D.V., Swisher, C.C., III, and Aubry, M.-P., 1995. A revised Cenozoic geochronology and chronostratigraphy. In Berggren, W.A., Kent, D.V., Aubry, M.-P., and Hardenbol, J. (Eds.), Geochronology, Time Scales and Global Stratigraphic Correlation. Spec. Publ.Soc. Econ. Paleontol. Mineral., 54:129-212.

Bukry, D., 1973. Low-latitude coccolith biostratigraphic zonation. In Edgar, N.T., Saunders, J.B., et al., Init. Repts. DSDP, 15: Washington (U.S. Govt. Printing Office), 685-703.

1975. Coccolith and silicoflagellate stratigraphy, northwestern Pacific Ocean, Deep Sea Drilling Project Leg 32. In Larson, R.L., Moberly, R., et al., Init. Repts. DSDP, 32: Washington (U.S. Govt. Printing Office), 677-701.
Cande, S.C., and Kent, D.V., 1992. A new geomagnetic polarity time scale for the Late Cretaceous and Cenozoic. J. Geophys. Res., 97:1391713951.

Cati, F. (Ed.), 1981. Search of the Palaeogene/Neogene Boundary Stratotype, I: Potential Boundary Stratotype Sections in Italy and Greece and a Comparison with Results from the Deep-Sea. G. Geol., 44.

Fornaciari, E., and Rio, D., 1996. Latest Oligocene to early middle Miocene quantitative calcareous nannofossil biostrartigraphy in the Mediterranean region. Micropaleontology, 42:1-36.

Gartner, S., 1974. Nannofossil biostratigraphy, Leg 22, Deep Sea Drilling Project. In von der Borch, C.C., Sclater, J.G., et al., Init. Repts. DSDP, 22: Washington (U.S. Govt. Printing Office), 577-599.

Haq, B.U., Hardenbol, J., and Vail, P.R., 1987. Chronology of fluctuating sea levels since the Triassic. Science, 235:1156-1167.

, 1988. Mesozoic and Cenozoic chronostratigraphy and cycles of sea-level change. In Wilgus, C.K., Hastings, B.S., Kendall, C.G.St.C., Posamentier, H.W., Ross, C.A., and Van Wagoner, J.C. (Eds.), Sea-Level Changes-An Integrated Approach. Spec. Publ.-Soc. Econ. Paleontol. Mineral., 42:72-108.

Keller, G., Herbert, T., Dorsey, R., D’Hondt, S., Johnsson, M., and Chi, W.R., 1987. Global distribution of late Paleogene hiatuses. Geology, 15:199-203.

Martini, E., 1971. Standard Tertiary and Quaternary calcareous nannoplankton zonation. In Farinacci, A. (Ed.), Proc. 2nd Int. Conf. Planktonic Microfossils Roma: Rome (Ed. Tecnosci.), 2:739-785.

, 1986. Paleogene calcareous nannoplankton from the Southwest Pacific Ocean, Deep Sea Drilling Project, Leg 90. In Kennett, J.P., von der Borch, C.C., et al., Init. Repts. DSDP, 90: Washington (U.S. Govt. Printing Office), 747-761.

Mascle, J., Lohmann, G.P., Clift, P.D., et al., 1996. Proc. ODP, Init. Repts., 159: College Station, TX (Ocean Drilling Program).

Miller, K.G., Aubry, M.-P., Khan, K.J., Melillo, A.J., Kent, D.V., and Berggren, W.A., 1985. Oligocene-Miocene biostratigraphy, magnetostratigraphy and isotopic stratigraphy of the western North Atlantic. Geology, 13:257-261.

Okada, H., and Bukry, D., 1980. Supplementary modification and introduction of code numbers to the low-latitude coccolith biostratigraphic zonation (Bukry, 1973; 1975). Mar. Micropaleontol., 5:321-325.

Perch-Nielsen, K., 1985. Cenozoic calcareous nannofossils. In Bolli, H.M., Saunders, J.B., and Perch-Nielsen, K. (Eds.), Plankton Stratigraphy: Cambridge (Cambridge Univ. Press), 427-554.

Perch-Nielsen, K., and Petters, S.W., 1981. Cretaceous and Eocene microfossil ages from the southern Benue Trough, Nigeria. Arch. Sc. Geneve, 34:211-218.

Shafik, S., 1983. Calcareous nannofossil biostratigraphy: an assessment of foraminiferal and sedimentation events in the Eocene of the Otway Basin, southeastern Australia. BMR J. Aust. Geol. Geophys., 8:1-17.

Shafik, S., and Chaproniere, G.C., 1978. Nannofossil and planktic foraminiferal biostratigraphy around the Oligocene-Miocene boundary in parts of the Indo-Pacific region. BMR J. Aust. Geol. Geophys., 3:135-151.

Shipboard Scientific Party, 1996a. Site 960. In Mascle, J., Lohmann, G.P., Clift, P.D., et al., Proc. ODP, Init. Repts., 159: College Station, TX (Ocean Drilling Program), 151-215.

, 1996b. Site 961. In Mascle, J., Lohmann, G.P., Clift, P.D., et al., Proc. ODP, Init. Repts., 159: College Station, TX (Ocean Drilling Program), 217-249.

Sissingh, W., 1977. Biostratigraphy of Cretaceous calcareous nannoplankton. Geol. Mijnbouw, 56:37-65.

Steininger, F.F., 1981. Conclusions on the biostratigraphic results of Italian and Greece sections. In Cati, F. (Ed.), Search of the Palaeogene/Neogene Boundary Stratotype, I: Potential Boundary Stratotype Sections in Italy and Greece and a Comparison with Results from the Deep-Sea. G. Geol., 44:189-193.

Steininger, F.F., and Proponents of the IUGS-ICS-SNS Working Group on the Paleogene/Neogene Boundary, 1994. Proposal for the Global Stratotype Section and Point (GSSP) for the Base of the Neogene (the Paleogene/Neogene Boundary). IGCP Project 329, The Working Group.

Toumarkine, M., Diop, A., and Perch-Nielsen, K., 1984. Foraminifères planctoniques et nannofossiles calcaires du Paléocène et de l'Eocène inférieur du Cap Vert, Sénégal. Geol. Mediterr., 11:1-11.

Date of initial receipt: 23 September 1996

Date of acceptance: 29 January 1997

Ms 159SR-015 


\section{APPENDIX}

\section{Calcareous Nannofossils Considered in This Chapter} (In Alphabetical Order of Generic Epithets)

\section{Paleogene Taxa}

Bomolithus conicus (Perch-Nielsen, 1971) Perch-Nielsen, 1984 Campylosphaera dela (Bramlette and Sullivan, 1961) Hay and Mohler, 1967 Campylosphaera eodela Bukry and Percival, 1971

Chiasmolithus bidens (Bramlette and Sullivan, 1961) Hay and Mohler, 1967

Chiasmolithus danicus (Brotzen, 1959) Hay and Mohler, 1967

Chiasmolithus californicus (Sullivan, 1961) Hay and Mohler, 1967

Chiasmolithus consuetus (Bramlette and Sullivan, 1961) Hay and Mohler, 1967

Chiasmolithus eograndis Perch-Nielsen, 1971

Chiasmolithus expansus (Bramlette and Sullivan, 1961) Gartner, 1970

Chiasmolithus gigas (Bramlette and Sullivan, 1961) Gartner, 1970

Chiasmolithus grandis (Bramlette and Riedel, 1954) Radomski, 1968

Chiasmolithus oamaruensis (Deflandre, 1954) Hay, Mohler and Wade, 1966

Chiasmolithus solitus (Bramlette and Sullivan, 1961) Locker, 1968

Chiasmoliths nitidus Gartner, 1970

Chiphrragmalithus acanthodes Bramlette and Sullivan, 1961

Chiphrragmalithus calathus Bramlette and Sullivan, 1961

Coccolithus crassus Bramlette and Sullivan, 1961

Coccolithus eopelagicus (Bramlette and Riedel, 1954) Bramlette and Sullivan, 1961

Coccolithus formosus (Kamptner, 1963) Wise, 1973

Coccolithus pelagicus (Wallich, 1877) Schiller, 1930

Coccolithus staurion Bramlette and Sullivan, 1961

Coronocyclus nitescens (Kamptner, 1963) Bramlette and Wilcoxon, 1967

Cruciplacolithus frequens (Perch-Nielsen, 1977) Romein, 1979

Cruciplacolithus tenuis (Stradner, 1961) Hay and Mohler, 1967

Cyclicargolithus abisectus (Müller, 1970) Wise, 1973

Cyclicargolithus floridanus (Roth and Hay in Hay et al., 1967) Bukry, 1971

Cyclicargolithus gammation (Bramlette and Sullivan, 1961) Shafik, 1990

Cyclicargolithus luminis (Sullivan, 1964) Bukry, 1971

Cyclicargolithus reticulatus (Gartner and Smith, 1967) Bukry, 1971

Daktylethra punctulata Gartner in Gartner and Bukry, 1969

Dictyococcites bisectus (Hay, Mohler and Wade, 1966) Bukry and Percival, 1971

Dictyococcites scrippsae Bukry and Percival, 1971

Discoaster barbadiensis Tan Sin Hok, 1929 emended Bramlette and Riedel, 1964

Discoaster bifax Bukry, 1971

Discoaster binodosus Martini, 1958

Discoaster calculosus Bukry, 1971

Discoaster cruciformis Martini, 1958

Discoaster deflandrei Bramlette and Riedel, 1964

Discoaster delicatus Bramlette and Sullivan, 1961

Discoaster diastypus Bramlette and Sullivan, 1961

Discoaster druggii Bramlette and Wilcoxon, 1967

Discoaster elegans Bramlette and Sullivan, 1961

Discoaster gemmifer Stradner, 1961

Discoaster kuepperi Stradner, 1959

Discoaster lenticularis Bramlette and Sullivan, 1961

Discoaster lidzi Hay in Hay et al., 1967

Discoaster lodoensis Bramlette and Riedel, 1964

Discoaster mirus Deflandre in Deflandre and Fert, 1954

Discoaster mohleri Bukry and Percival, 1971

Discoaster multiradiatus Bramlette and Riedel, 1964

Discoaster nephados Hay in Hay et al., 1967

Discoaster nobilis Martini, 1961

Discoaster nodifer (Bramlette and Riedel, 1954) Bukry, 1973

Discoaster praebifax Wei and Wise, 1989

Discoaster saipanensis Bramlette and Riedel, 1954

Discoaster salisburgensis Stradner, 1961

Discoaster saundersi Hay in Hay et al., 1967

Discoaster splendidus Martini, 1960

Discoaster strictus Stradner, 1961

Discoaster sublodoensis Bramlette and Sullivan, 1961

Discoaster tanii Bramlette and Riedel, 1954

Discoaster wemmelensis Achutan and Stradner, 1969

Ellipsolithus distichus (Bramlette and Sullivan, 1961) Sullivan, 1964

Ellipsolithus lajollaensis Bukry and Percival, 1971

Ellipsolithus macellus (Bramlette and Sullivan, 1961) Sullivan, 1964

Ericsonia subdisticha (Roth and Hay in Hay et al., 1967) Roth in Baumann and Roth, 1969
Ericsonia robusta (Bramlette and Sullivan, 1961) Perch-Nielsen, 1977

Fasciculithus alanii Perch-Nielsen, 1971

Fasciculithus clinatus Bukry, 1971

Fasciculithus involutus Bramlette and Sullivan, 1961

Fasciculithus lilianae Perch-Nielsen, 1971

Fasciculithus richardii Perch-Nielsen, 1971

Fasciculithus tympaniformis Hay and Mohler in Hay et al., 1967

Helicosphaera dinesenii (Perch-Nielsen, 1971) Jafar and Martini, 1975

Helicosphaera euphratis Haq, 1966

Helicosphaera gartneri Theodoridis, 1984

Helicosphaera intermedia Martini, 1965

Helicosphaera lophota (Bramlette and Sullivan, 1961) Jafar and Martini, 1975

Helicosphaera obliqua Bramlette and Wilcoxon, 1967

Helicosphaera papillata (Bukry and Bramlette, 1969) Jafar and Martini, 1975

Helicosphaera recta (Haq, 1966) Jafar and Martini, 1975

Helicosphaera seminulum (Bramlette and Sullivan, 1961) Jafar and Martini, 1975

Helicosphaera truempyi Biolzi and Perch-Nielsen, 1982

Heliolithus cantabriae Perch-Nielsen, 1971

Heliolithus kleinpellii Sullivan, 1964

Heliolithus megastypus (Bramlette and Sullivan, 1961) Romein, 1979

Heliolithus riedelii Bramlette and Sullivan, 1961

Holodiscolithus Roth, 1970

Hornibrookina australis Edwards and Perch-Nielsen, 1975

Isthmolithus recurvus Deflandre, in Deflandre and Fert, 1954

Lophodolithus mochlophorus Deflandre in Deflandre and Fert, 1954

Lophodolithus nascens Bramlette and Sullivan, 1961

Markalius inversus (Deflandre in Deflandre and Fert, 1954) Bramlette and Martini, 1964

Micrantholithus Deflandre, 1950

Nannotetrina cristata (Martini, 1958) Perch-Nielsen, 1971

Nannotetrina fulgens (Stradner, 1960) Aachutan and Stradner, 1969

Nannotetrina mexicana (Stradner, 1959) Bukry, 1973

Nannotetrina pappii (Stradner, 1959) Perch-Nielsen, 1971

Neochiastozygus junctus (Bramlette and Sullivan, 1961) Perch-Nielsen, 1971

Neococcolithes dubius (Deflandre, 1954) Black, 1967

Pemma Klumpp, 1953

Placozygus sigmoides (Bramlette and Sullivan, 1961) Romein, 1979

Pontosphaera Lohmann, 1902

Pontosphaera multipora (Kamptner, 1948) Roth, 1970

Pontosphaera pygmaea (Locker, 1967) Bystrická and Lehotayová, 1974

Pseudotriquetrorhabdulus inversus (Bukry and Bramlette, 1969) Bukry, 1981, emended Wise, 1983

Reticulofenestra dictyoda (Deflandre and Fert, 1954) Stradner in Stradner and Edwards, 1968

Reticulofenestra gartneri Roth and Hay in Hay et al., 1967

Reticulofenestra lockeri Müller, 1970

Reticulofenestra samodurovii (Hay, Mohler and Wade, 1966) Roth, 1970

Reticulofenestra umbilicus (Levin, 1965) Martini and Ritzkowski, 1968

Rhabdosphaera inflata Bramlette and Sullivan, 1961

Rhomboaster bitrifida Romein, 1979

Sphenolithus anarrrhopus Bukry and Bramlette, 1969

Sphenolithus capricornutus Bukry and Percival, 1971

Sphenolithus ciperoensis Bramlette and Wilcoxon, 1967

Sphenolithus compactus Backman, 1980

Sphenolithus conicus Bukry, 1971

Sphenolithus delphix Bukry, 1973

Sphenolithus dissimilis Bukry and Percival, 1971

Sphenolithus distentus (Martini, 1965) Bramlette and Wilcoxon, 1967

Sphenolithus elongatus Perch-Nielsen, 1980

Sphenolithus furcatolithoides Locker, 1967

Sphenolithus moriformis (Brönnimann and Stradner, 1960) Bramlette and Wilcoxon, 1967

Sphenolithus orphanknollensis (Perch-Nielsen, 1971) Perch-Nielsen, 1985

Sphenolithus predistentus Bramlette and Wilcoxon, 1967

Sphenolithus primus Perch-Nielsen, 1971

Sphenolithus pseudoradians Bramlette and Wilcoxon, 1967

Sphenolithus radians Deflandre in Grassé, 1952

Sphenolithus spiniger Bukry, 1971

Toweius eminens (Bramlette and Sullivan, 1961) Gartner, 1971

Toweius magnicrassus (Bukry, 1971) Romein, 1979

Toweius pertusus (Sullivan, 1965) Romein, 1979

Toweius tovae Perch-Nielsen, 1971

Transversopontis Hay, Mohler and Wade, 1966 
Transversopontis pulcher (Deflandre, in Deflandre and Fert, 1954) Hay, Mohler and Wade, 1966

Transversopontis pulcheroides (Sullivan, 1964) Báldi-Beke, 1971

Tribrachiatus bramlettei (Brönnimann and Stradner, 1960) Proto Decima et al., 1975

Tribrachiatus contortus (Stradner, 1958) Bukry, 1972

Tribrachiatus orthostylus (Bramlette and Riedel, 1954) Shamray, 1963

Triquetrorhabdulus auritus Stradner and Allram, 1982

Triquetrorhabdulus carinatus Martini, 1965
Trochoaster Klumpp, 1953

Zygodiscus herlynii Sullivan, 1964

Zygrhablithus Deflandre, 1959

Zygrhablithus bijugatus (Deflandre, in Deflandre and Fert, 1954) Deflandre, 1959

\section{Reworked Cretaceous Taxa}

Prediscosphaera cretacea (Arkhangelsky, 1912) Gartner, 1968 


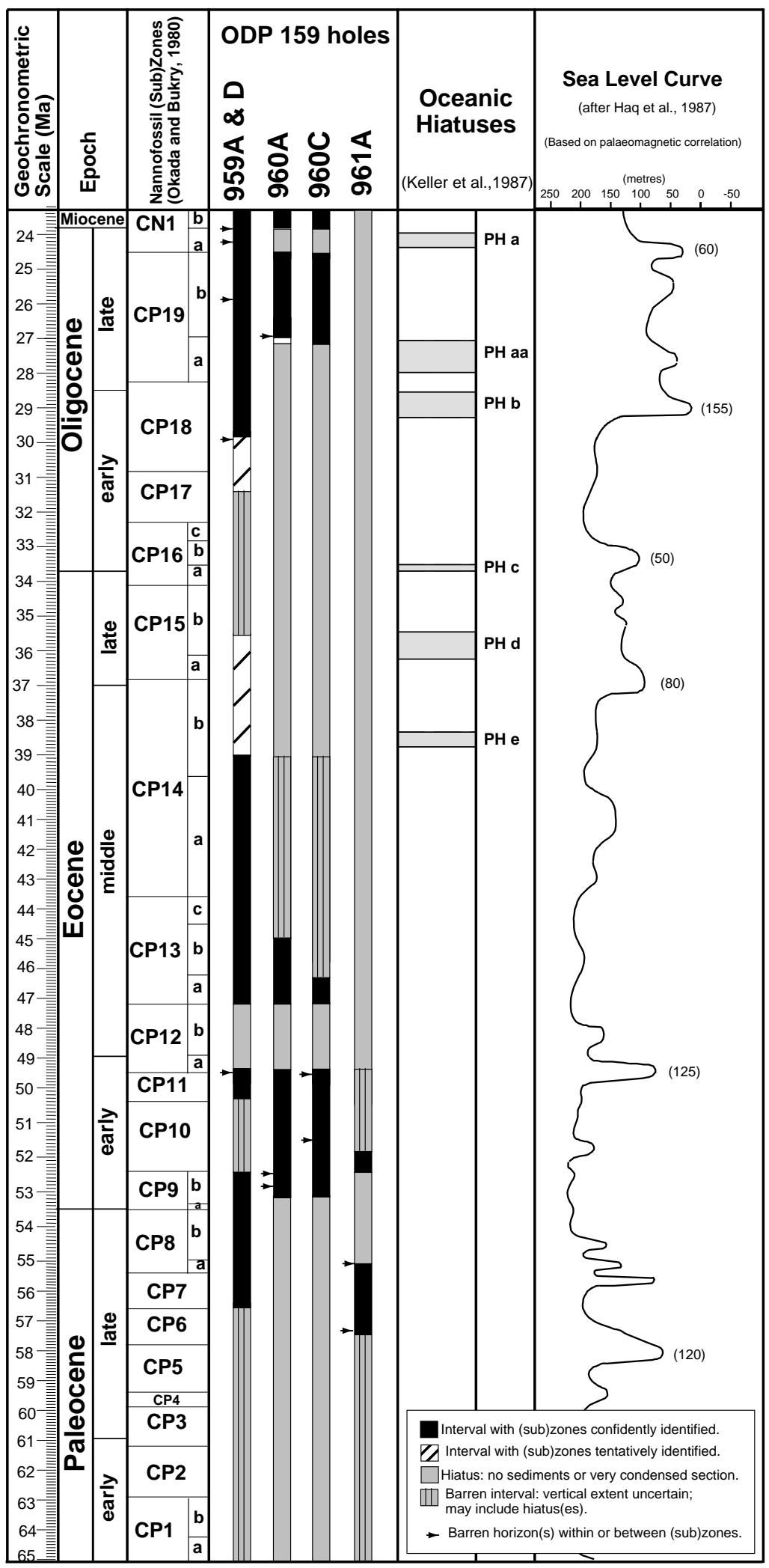

Figure 3. Sea-level curve, oceanic hiatuses and the Paleogene on the Côte d'Ivoire-Ghana Marginal Ridge, ODP Leg 159. In the column of oceanic hiatuses no data are available below the PHe hiatus. In the column of sea-level curve, figures between brackets are total sea level falls in meters. Note the strong correlation between the major drop of global sea level during the late early Eocene of $\sim 125 \mathrm{~m}$ and the coeval hiatus at Sites 960 (on the crest of the Marginal Ridge) and 959 (on the shoulder of the Marginal Ridge), also the temporal match of the late Oligocene hiatus at Site 960, the PHa hiatus of Keller et al. (1987), and the drop of $\sim 60 \mathrm{~m}$ in global sea level. 

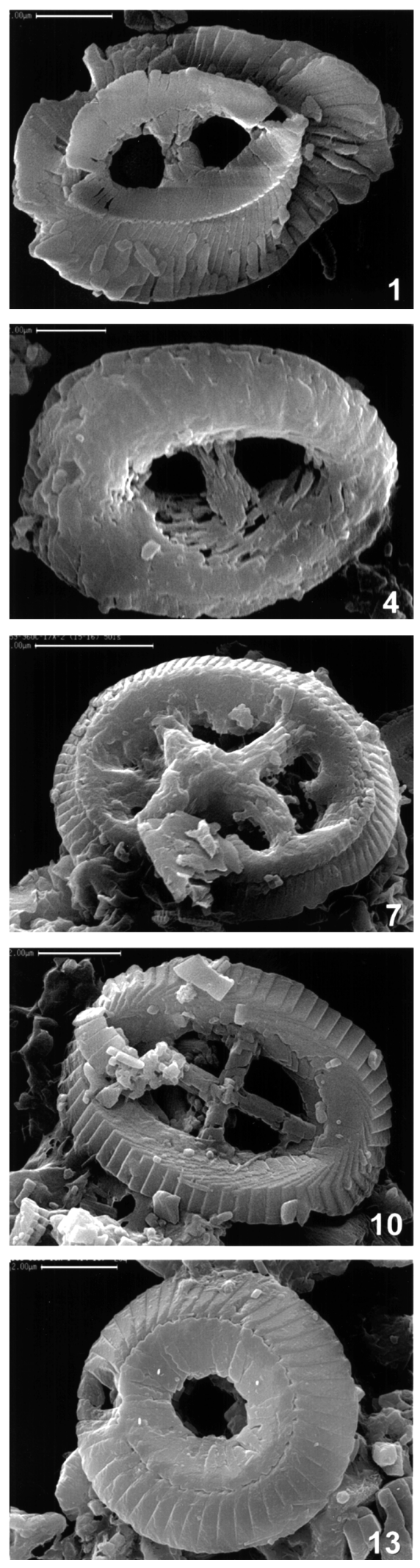
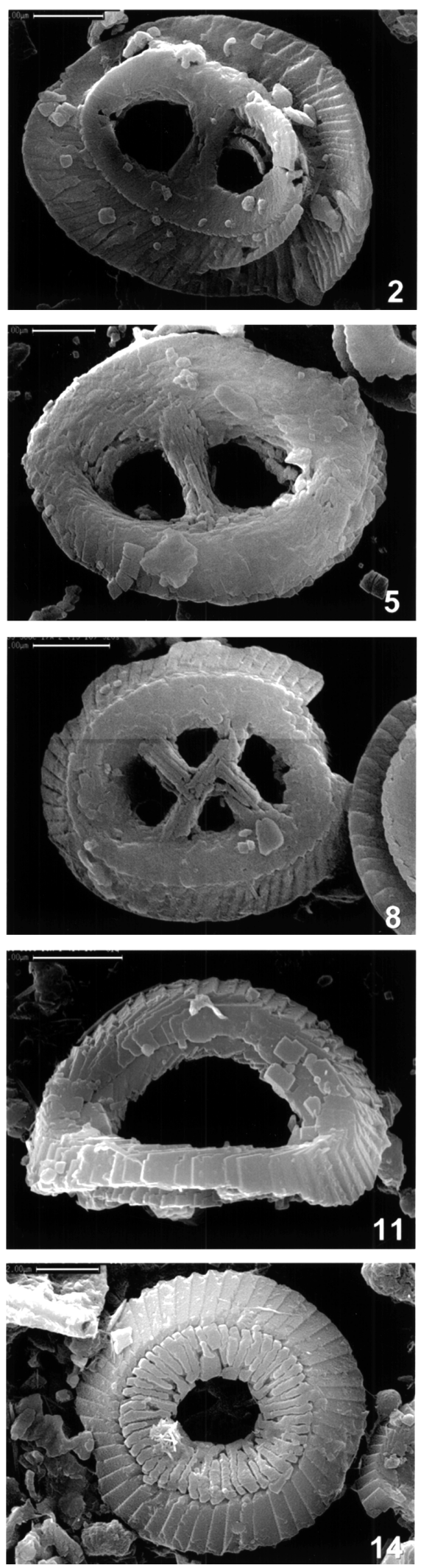
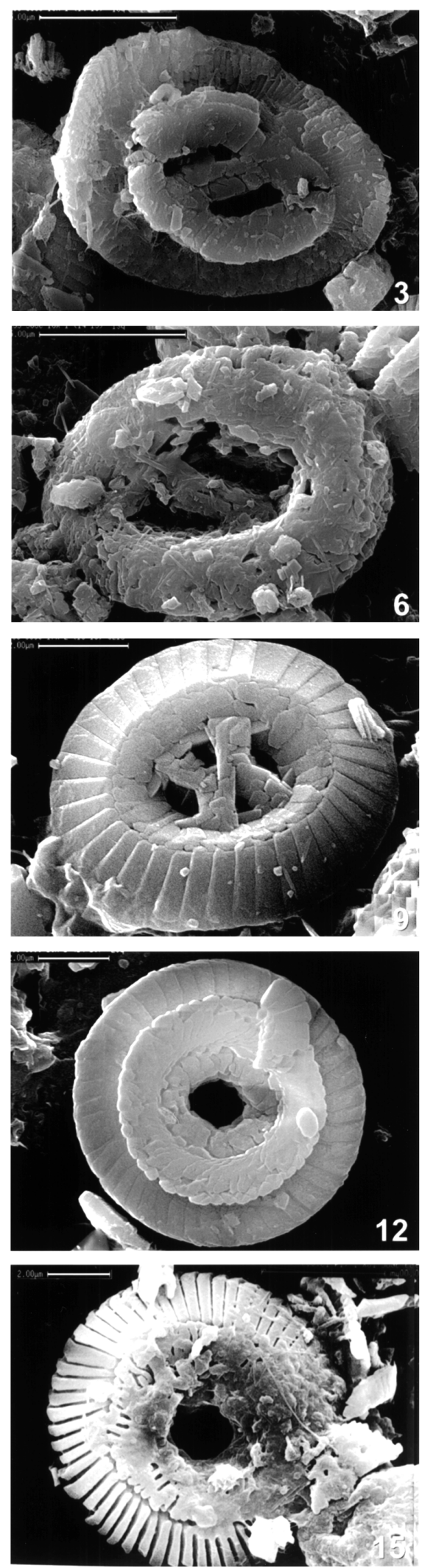

Plate 1. Eocene nannofossils from Site 260. 1, 2, 4, 5. Helicosphaera seminulum, Sample 159-960C-17X-2, 15-16 cm, scale bar $=2 \mu \mathrm{m}: 1,2$. proximal views; 4, 5. distal views. 3, 6. Helicosphaera lophota, Sample 159-960C-18X-1, 14-15 cm, scale bar $=5 \mu \mathrm{m}$ : 3. proximal view; 6. distal view. 7. Chiasmolithus grandis distal view, Sample 159-960C-18X-1, 14-15 cm, scale bar $=5 \mu \mathrm{m} . \mathbf{8}, 9$. Chiasmolithus solitus distal view, Sample 159-960C-17X-2, 15-16 cm, scale bar $=2$ $\mu \mathrm{m}$. 9. Chiasmolithus consuetus distal view, Sample 159-960C-17X-2, $15-16 \mathrm{~cm}$, scale bar $=2 \mu \mathrm{m}$. 10, 11. Campylosphaera dela distal views, scale bar $=2 \mu \mathrm{m}$ : 10. Sample 159-960C-17X-2, 15-16 cm; 11. Sample 159-960C-18X-1, 14-15 cm. 12-15. Coccolithus formosus, Sample 159-960C-18X-1, 14-15 cm; scale bar $=2 \mu \mathrm{m}$ : 12. proximal view; 13-15. distal views showing various degrees of dissolution. 

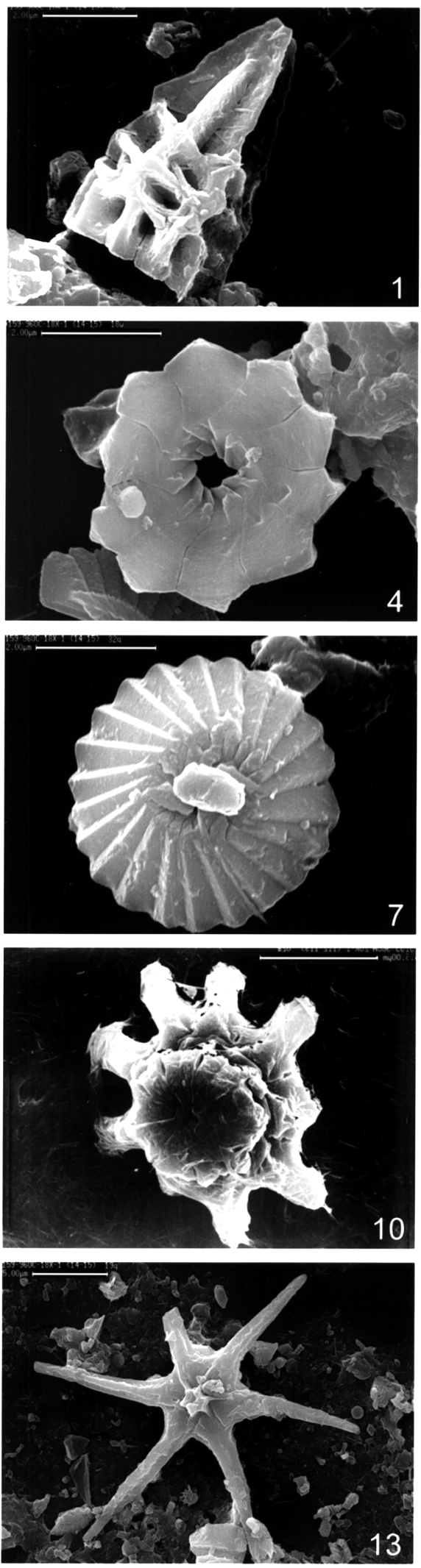
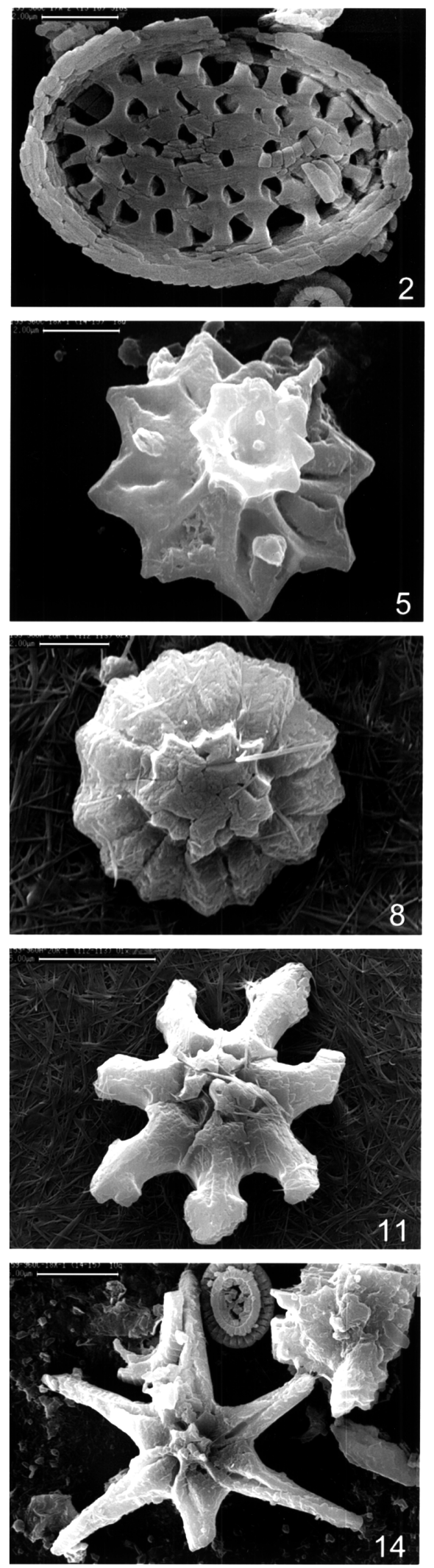
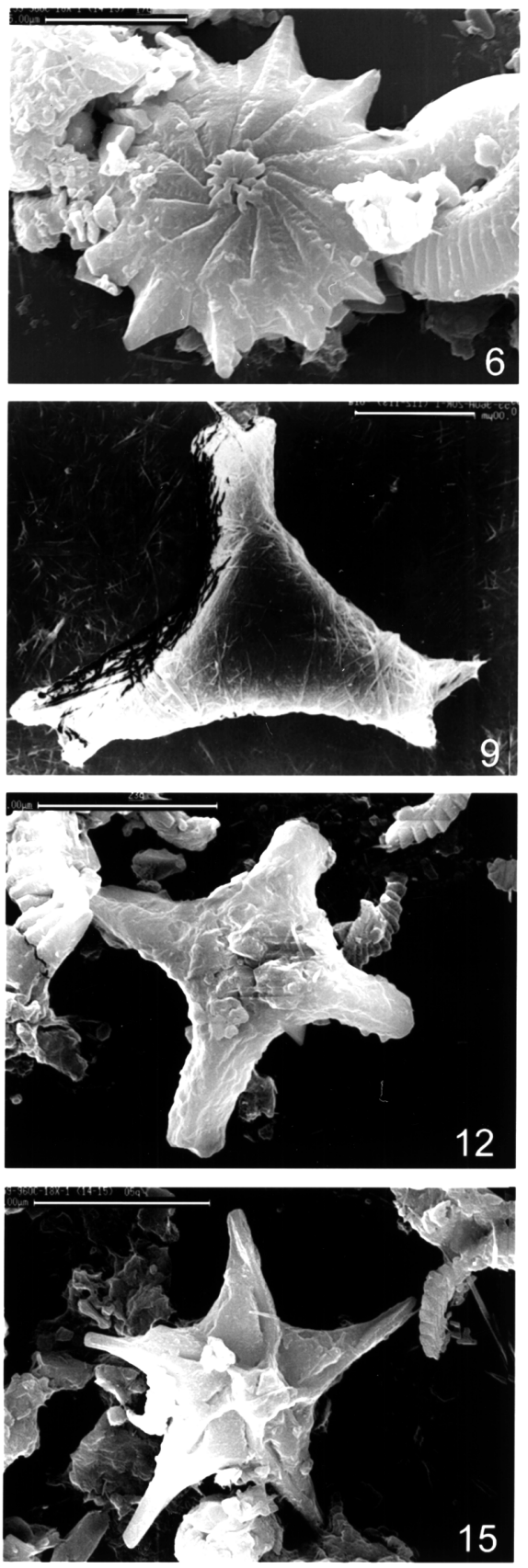

Plate 2. Eocene nannofossils from Site 260. 1. Sphenolithus radians, Sample 159-960C-18X-1, $14-15 \mathrm{~cm}$, scale bar $=2 \mu \mathrm{m}$. 2. Pontosphaera multipora distal view, Sample 159-960C-17X-2, 15-16 cm, scale bar $=2 \mu \mathrm{m}$. 3. Neococcolithes dubius distal view, Sample 159-960C-17X-2, 15-16 cm, scale bar = $2 \mu \mathrm{m} .4,5$. Discoaster kuepperi, Sample 159-960C-18X-1, 14-15cm, scale bar $=2 \mu \mathrm{m}: 4$. ?proximal view; 5. ?distal view. 6. Discoaster barbadiensis, Sample 159-960C$18 \mathrm{X}-1,14-15 \mathrm{~cm}$, scale bar $=5 \mu \mathrm{m}$. 7. Discoaster lenticularis, Sample 159-960C-18X-1, 14-15 cm, scale bar $=2 \mu \mathrm{m}$. 8. Discoaster sp. aff. D. mohleri, Sample 159-960A-20R-1, 112-113 cm, scale bar $=2 \mu \mathrm{m}$. 9. Tribrachiatus orthostylus, Sample 159-960A-20R-1, 112-113 cm, scale bar $=5 \mu \mathrm{m} .10$, 11. Discoaster binodosus, Sample 159-960A-20R-1, 112-113 cm, scale bar $=5 \mu \mathrm{m}$. 12. Discoaster cruciformis, Sample 159-960C-18X-1, $14-15 \mathrm{~cm}, \mathrm{scale}$ bar $=5 \mu \mathrm{m} .13$, 14. Discoaster lodoensis, Sample 159-960C-18X-1, 14-15 cm, scale bar $=5 \mu \mathrm{m}$. 15. Discoaster sp. aff. D. sublodoensis, Sample 159-960C-18X-1, 14-15 cm, scale bar $=2 \mu \mathrm{m}$. Note: Sample 159-960A-20R-1, 112-113 cm came from the palygorskite claystone unit at the site. 